ISSN (print): 1698-6180. ISSN (online): 1886-7995

www.ucm.es/info/estratig/journal.htm

Journal of Iberian Geology 38 (2) 2012: 349-372

http://dx.doi.org/10.5209/rev_JIGE.2012.v38.n2.40463

\title{
Rodents and insectivores from the Lower Miocene (Agenian and Ramblian) of the Tudela Formation (Ebro Basin, Spain)
}

\author{
Roedores e insectívoros del Mioceno Inferior (Ageniense y Rambliense) \\ de la Formación Tudela (Cuenca del Ebro, España)
}

\author{
F. J. Ruiz-Sánchez ${ }^{1 *}$ X. Murelaga ${ }^{2}$, M. Freudenthal ${ }^{3,4}$, J. C. Larrasoaña ${ }^{5}$, M. Furió ${ }^{6}$, M. Garcés ${ }^{7}$, \\ M. González-Pardos ${ }^{1}$, O. Suarez-Hernando ${ }^{2}$ \\ ${ }^{1}$ Departament de Geologia. Universitat de València, 46100 Burjassot, Spain \\ francisco.ruiz@uv.es; magonpar@alumni.uv.es. \\ ${ }^{2}$ Departamento de Estratigrafia y Paleontología, Universidad del País Vasco, 48080 Bilbao, Spain \\ xabier.murelaga@ehu.es; oiersuarez@gmail.com. \\ ${ }^{3}$ Departamento de Estratigrafia y Paleontología, Universidad de Granada, 18071 Granada, Spain.mfreuden@ugr.es \\ ${ }^{4}$ Netherlands Centre for Biodiversity, Naturalis, Leiden, The Netherlands. \\ ${ }^{5}$ Instituto Geológico y Minero de España, Unidad de Zaragoza, 50006 Zaragoza, Spain.jc.larra@igme.es. \\ ${ }^{6}$ Institut Català de Paleontologia M. Crusafont, Edifici ICP, Universitat Autònoma de Barcelona, Cerdanyola del \\ Vallès, 08193 Barcelona, Spain, marc.furio@icp.cat. \\ ${ }^{7}$ Grup de Geodinàmica i Anàlisi de Conques, Universitat de Barcelona, Zona Universitaria de Pedralbes, 08028 \\ Barcelona,Spain,mgarces@ub.edu.
}

*corresponding author

Received: 12/12/2011 / Accepted: 02/04/2012

\begin{abstract}
The rodent and insectivore faunas of Agenian and Ramblian age from the Tudela Formation (Ebro Basin, Spain) are described. Four of the localities (CH1, CA1, CC1 and CA2) contain rodent remains of Agenian age (local zone Y), and three (CA3, CA3B and CA4) of Ramblian age (local zones Z and A). Typical Agenian taxa include Armantomys cf. bijmai (CH1), Eucricetodon cf. gerandianus (CA1), Peridyromys turbatus, Simplomys aff. aljaphi and Armantomys daamsi (CA2) and Eucricetodon aff. aquitanicus (CC1). On the other hand, some typical Ramblian taxa are Armantomys cf. parsani (CA3), Ligerimys aff. magnus and Pseudotheridomys sp. (CA4) and Prodryomys cf. brailloni (CA3B). The faunas are characterized by the richness and diversity of the glirids. The presence of the glirid Altomiramys in CA4 represents the first Upper Ramblian record of this taxon.
\end{abstract}

Keywords: Rodentia, Insectivora, Ebro Basin, Miocene, MN2, MN3 


\section{Resumen}

En este trabajo se describen las faunas de roedores e insectívoros de edad Ageniense y Rambliense de la Formación Tudela (Cuenca del Ebro, España). Cuatro de las localidades (CH1, CA1, CC1 y CA2) contienen restos de edad Ageniense (zona local Y), y tres (CA3, CA3B y CA4) de edad Rambliense (zonas locales Z y A). Entre otras, las faunas Agenienses incluyen a Armantomys cf. bijmai (CH1), Eucricetodon cf. gerandianus (CA1), Peridyromys turbatus, Simplomys aff. aljaphi y Armantomys daamsi (CA2) y Eucricetodon aff. aquitanicus (CC1). Del mismo modo, entre las faunas Ramblienses se incluye a Armantomys cf. parsani (CA3), Ligerimys aff. magnus y Pseudotheridomys sp. (CA4) y Prodryomys cf. brailloni (CA3B). Las faunas encontradas en estos yacimientos se caracterizan por la riqueza y diversidad de glíridos. La presencia del glírido Altomiramys en CA4, representa el primer registro de este taxon en el Rambliense superior.

Palabras clave: Rodentia, Insectivora, Cuenca del Ebro, Mioceno, MN2, M1

\section{Introduction}

In the past two decades, our team has performed an extensive paleontological investigation in the Bardenas Reales of Navarra, in the western part of the central sector of the Ebro Basin (see Murelaga, 2000). This led to ample knowledge of the vertebrate fauna of Ramblian age (Lower Miocene) of the deposits of the Tudela Formation (Larrasoaña et al., 2006), including mammals (Murelaga et al., 2004a, 2004b), amphibians, reptiles (Murelaga et al., 2002) and birds (Murelaga, 2000). The paleontological knowledge of the Ramblian deposits is accompanied by a magnetostratigraphical characterization (Larrasoaña et al., 2006), allowing to establish a detailed chronology of the fossiliferous sites.

Seven new fossiliferous levels have been found $(\mathrm{CH}$, $\mathrm{CC} 1, \mathrm{CA} 1, \mathrm{CA} 2, \mathrm{CA} 3, \mathrm{CA} 3 \mathrm{~B}$ and CA4) (Table 1) in the lower part of the Tudela Formation. Recently, RuizSánchez et al. (2012) have described the remains of hypsodont glirids of the genera Armantomys de Bruijn, 1966 and Praearmantomys de Bruijn, 1966 from several of these sites (CH1, CC1, CA2, CA3 and CA4) (Table 1). The first practical result of this work are, on the one hand, the proposal of a biostratigraphical sequence of the sediments of the Lower Miocene of the Ebro Basin and, on the other hand, the proposition of the chronostratigraphical position of the Agenian-Ramblian boundary in the Iberian Peninsula. In this contribution we present a complete study of the micromammal faunas of the seven new sites found in the basal part of the Tudela Formation, which permits a detailed biostratigraphical definition and to confirm the calibration of the Agenian-Ramblian boundary, proposed by Ruiz-Sánchez et al. (2012) on the basis of hypsodont glirids only.

\section{Material, methods and abbreviations}

The fossils were collected during the campaigns of 2004 and 2006. The samples were excavated and transported to Cenicero (La Rioja). Sieving was done in this locality with a sieve with $0.5 \mathrm{~mm}$. mess. The fossils are deposited in the 'Departamento de Estratigrafía y Paleontología de la Universidad del País Vasco' (UPV/EHU). The nomenclature used in the description of the teeth and the measurement methods are taken from Fahlbusch (1970), Álvarez-Sierra (1988) (Eomyidae), Mein and Freudenthal (1971) (Cricetidae), Cuenca (1988) (Sciuridae), Hugueney (1999b) (Castoridae) and Freudenthal (2004) (Gliridae). The measurements are given in units of $0.1 \mathrm{~mm}$, and were taken on a binocular microscope Leica $\mathrm{MZ7}_{5}$, by means of displacement of a mechanical stage, connected to a Sony Magnescale measuring equipment.

Lower teeth are coded as p4, m1, m2, m3, upper teeth as P4, M1, M2 and M3. We use the MN units (European

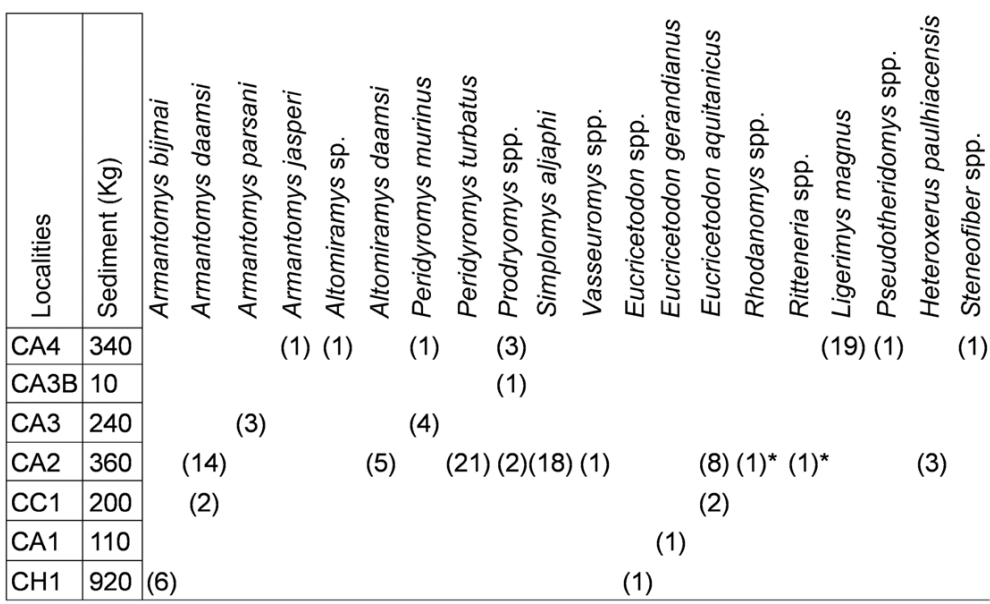

Table 1.- Fossil localities and number of specimens for each species. Asterisks indicate assignation of this fossil remain to Rhodanomys or Ritteneria genera.

Tabla 1.- Número de especímenes por especie y localidad. Los asteriscos indican la asignación del resto en cuestión al género Rhodanomys o Ritteneria. 


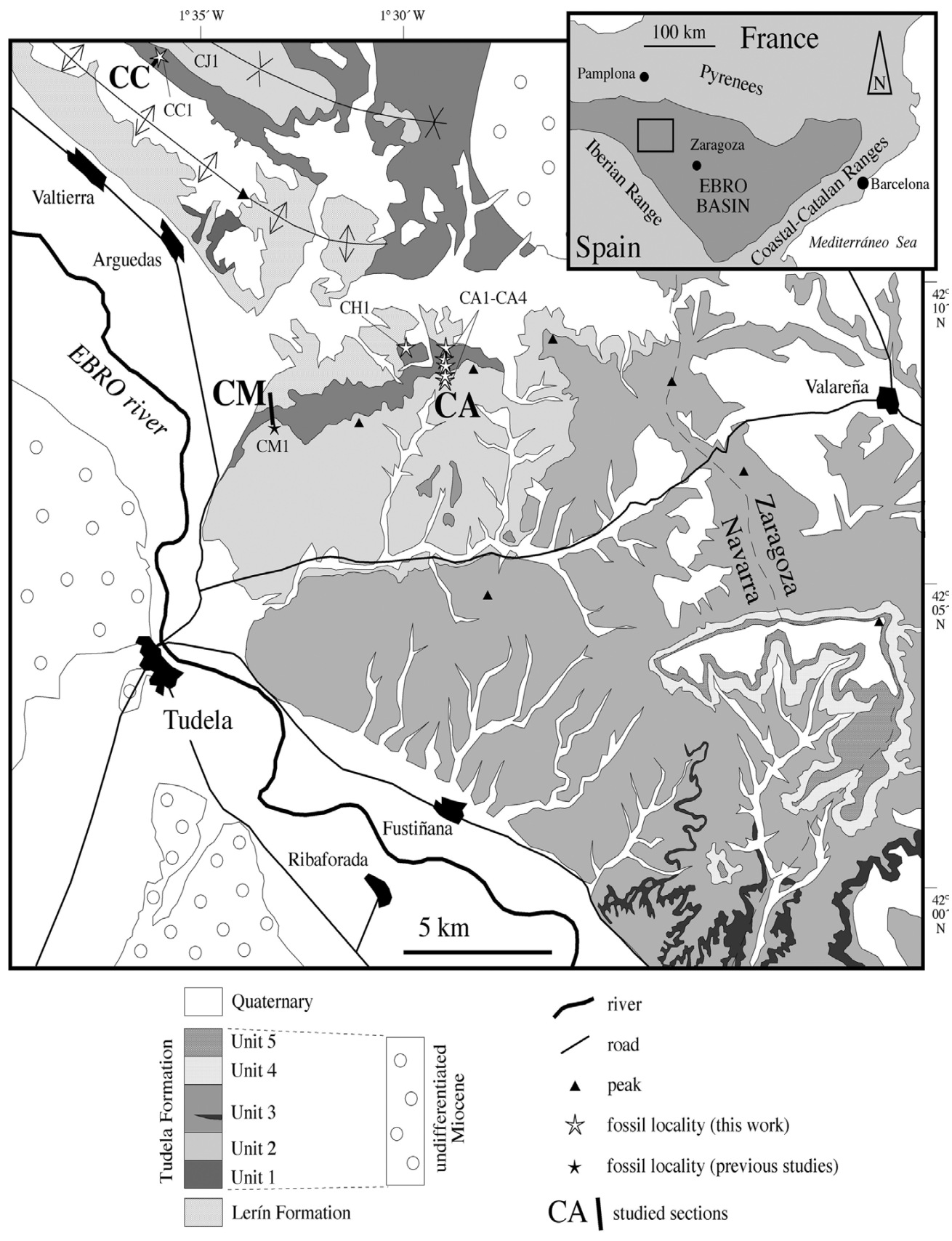

Fig. 1.- Geological map of the Tudela Formation in the Bardenas Reales of Navarra, with the situation of the localities presented in this work. CH1: Cabezo Hermoso, CC1: Cabezo Carboneras 1, CA1 to CA4: Cuesta Agujeros 1 to 4. Also shown the situation of other localities previously studied in the lower part of the Tudela Formation (Murelaga, 2000; Murelaga et al., 2004a,b).

Fig. 1.- Mapa geológico de la Formación Tudela en Las Bardenas Reales de Navarra, con la situación de las localidades presentadas en este trabajo. CH1: Cabezo Hermoso, CC1: Cabezo Carboneras 1, CA1 to CA4: Cuesta Agujeros 1 a 4. Así mismo se muestra la situación de las otras localidades previamente estudiadas en la parte inferior de la Formación Tudela (Murelaga, 2000; Murelaga et al., 2004a,b).
Neogene land mammal units) or the local zones defined by Álvarez-Sierra et al. (1987), Daams and Freudenthal (1988), Daams et al. (1999) and/or van der Meulen et al. (2012).

Institutional and locality abbreviations.SCSIE(UV), Servei Central de Suport a la Investigació Experimental de la Universitat de València, Burjassot, Spain; UPV/EHU, Universidad del País Vasco/Euskal Herriko Unibertsitatea, Bilbao, Spain; CA1, Cuesta Agujeros 1; CA2, Cuesta Agujeros 2; CA3, Cuesta Agujeros 3; CA3B, Cuesta Agujeros 3B; CA4, Cuesta Agujeros 4; CC1, Cabezo Carboneras 1; CH1, Cabezo Hermoso 1; L, length; MN, European Neogene land mammal units; $\mathrm{W}$, width.

\section{Geological setting}

The Ebro Basin developed during the Tertiary as foreland basin of the Pyrenean, Iberian and Coastal-Catalan Cordilleras (Fig. 1). From the Late Eocene onwards, when the basin lost its connection with the Atlantic (Costa et al., 2010), and until the Late Miocene, when it began to drain towards the Mediterranean (Urgeles et al., 2011), the Ebro Basin was an endorrheic depression in which the fluvial systems that drained the surrounding mountains converged. These systems flowed into the central zone of the basin, where, depending on the climatic conditions, carbonatated fresh-water lakes or evaporitic systems formed (Alonso-Zarza et al., 2002). 
The Tudela Formation is composed of 655 meters of fluvial distal, palustrine and lacustrine sediments accumulated during the Early and Middle Miocene in the central part of the Western sector of the basin (Larrasoaña et al., 2006) and crops out extensively in the so-called Bardenas Reales of Navarra (Fig.1). The sediments are grey, yellowish, brown and reddish lutites with frequent intercalations of sandstones and limestones, and occasionally gypsum levels. The sandstone layers vary in thickness between 10 and $300 \mathrm{~cm}$, are associated with reddish and brownish lutites, and present predominantly tabular geometries. The limestones frequently show bioturbations and include abundant remains of gastropods, ostracods and charophytes, as well as other organisms. The limestone levels are up to $200 \mathrm{~cm}$ thick, and are frequently grouped in packets of decametric thickness. The sedimentary facies represented in the Tudela Formation are similar to those described in other sectors of the cen-

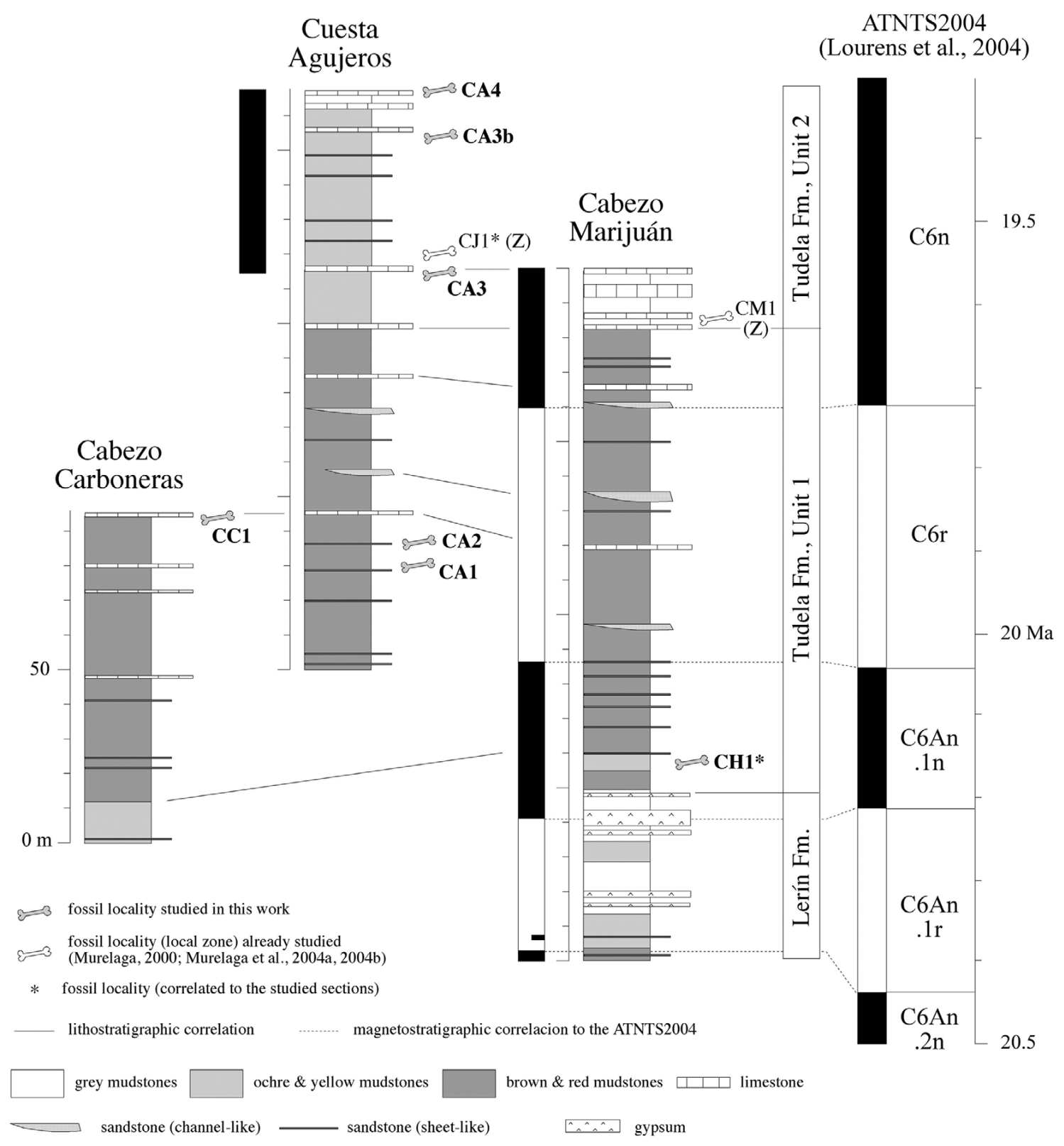

Fig. 2.- Stratigraphy of the Tudela Formation in the studied sections, with the localities presented in this work and other localities studied previously (Murelaga 2000; Murelaga et al. 2004a,b; Larrasoaña et al. 2006), and with the paleomagnetic sequence of the higher part of the section of Cuesta Agujeros and of the section of Cabezo Marijuán (see Larrasoaña et al. 2006), correlated with the ATNTS time scale of Lourens et al. (2004).

Fig. 2.- Estratigrafía de la Formación Tudela en las secciones estudiadas, con indicación de las localidades presentadas en este trabajo y en otros estudios previos (Murelaga, 2000; Murelaga et al., 2004a,b; Larrasoaña et al., 2006), y con la secuencia paleomagnética de la parte superior de las secciones de Cuesta Agujeros y Cabezo Marijuán (ver Larrasoaña et al., 2006), correlacionada con la escala de tiempo ATNTS de Lourens et al. (2004). 
tral part of the basin (Arenas and Pardo, 1999; AlonsoZarza et al., 2002). The sandstones and the reddish and brown clays indicate the deposition in distal floodplains, whereas the sequences dominated by limestones and grey lutites indicate lacustrine zones. The palustrine transition between these zones is represented by yellowish and grey lutites that include thin intercalations of sandstones and limestones.

The fossil sites presented in this work are located in three sections that span the two lower units of the Tudela Formation (Figs. 1 and 2). Unit 1 is characterized by the predominance of fluvial distal facies with occasional intercalations of palustrine facies; unit 2 is characterized by the predominance of lacustrine and palustrine facies (Fig. 2) (Larrasoaña et al., 2006). The sites studied in this work are situated in grey lutites of palustrine origin, except for CA2, which is in sandstone (Fig. 2). The lithostratigraphic correlation between the sections, together with available magnetostratigraphic data (Larrasoaña et al., 2006), permit dating the fossiliferous sites between 19.65 and 17.5 Ma (Burdigalian) according to ATNTS2004 (Lourens et al., 2004) (Fig. 2).

\section{Systematic paleontology}

Order: Rodentia Bowdich, 1821

Family: Cricetidae Fischer, 1817

Genus: Eucricetodon Thaler, 1966

Type species: Cricetodon collatus Schaub, 1925

Species: Eucricetodon sp.

(Fig. 3/1)

\section{Locality: Cabezo Hermoso $1(\mathrm{CH} 1)$}

Material: 1 incomplete $\mathrm{m} 1$ (CH1-1)

\section{Description:}

$\mathrm{m} 1$ : Anteroconid, protoconid and metaconid are high, round cusps. The anteroconid is pointed and displaced towards the labial part of the tooth, presenting two anterolophids that connect with protoconid and metaconid. The labial anterolophid is low and connected to the base of the protoconid, whereas the lingual one is high and connected to the metaconid. The wall formed by anteroconid, lingual anterolophid and metaconid closes the anterosinusid completely. Anterolophulid absent.

Remarks: This small fragment is similar to the morphology described by Thaler (1966) for the $\mathrm{m} 1$ of Eucricetodon. The presence of inflated cusps, and the not divided anteroconid of the $\mathrm{m} 1$ of $\mathrm{CH} 1$ is characteristic of the different species of Eucricetodon.
Species: Eucricetodon cf. gerandianus (Schaub, 1925)

(Fig. 3/2)

\section{Locality: Cuesta Agujeros 1 (CA1)}

Material and measurements ( $L x W): 1 \mathrm{ml}$ (CA1-1) $(22.10 \times 12.60)$

\section{Description:}

$\mathrm{m} 1$ : Anteroconid labially extended. Anterolophulid low and complete, connected to the anteroconid. Protoconid connected to the metaconid through the labial spur of the metalophulid. Metaconid connected to the anteroconid by a short crest that runs along the lingual part of the anterosinusid. Lingual wall of the metaconid moderately developed, without closing the mesosinusid. Mesoconid robust, developed towards the sinusid as well as to the mesosinusid. Mesolophid short.
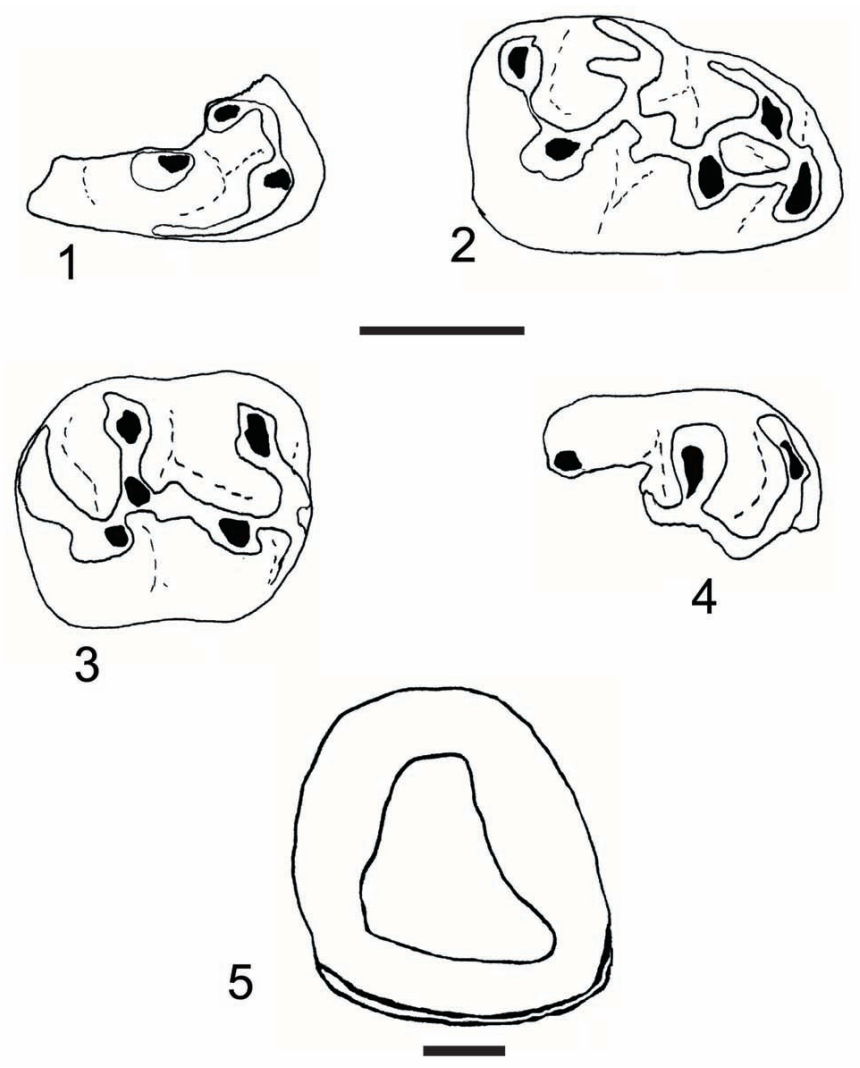

Fig. 3.- Eucricetodon sp. from Cabezo Hermoso 1 (CH1). 1, m1 dext. (CH1-1); Eucricetodon cf. gerandianus (Schaub, 1925) from Cuesta Agujeros 1 (CA1). 2, m1 dext. (CA1-1); Eucricetodon aff. aquitanicus Baudelot and de Bonis, 1968 from Cabezo Carboneras 1 (CC1). 3, $\mathrm{m} 2$ dext. (CC1-1); 4, m1,2 sin. (CC1-2); Steneofiber sp. from Cuesta Agujeros 4 (CA4). 5, Upper incisor (CA4-8). Scale: $1 \mathrm{~mm}$.

Fig. 3.- Eucricetodon sp. de Cabezo Hermoso 1 (CH1). 1, m1 dext. (CH1-1); Eucricetodon cf. gerandianus (Schaub, 1925) de Cuesta Agujeros 1 (CA1). 2, m1 dext. (CA1-1); Eucricetodon aff. aquitanicus Baudelot and de Bonis, 1968 de Cabezo Carboneras 1 (CC1). 3, $\mathrm{m} 2$ dext. (CC1-1); 4, m1,2 sin. (CC1-2); Steneofiber sp. de Cuesta Agujeros 4 (CA4). 5, Incisivo superior (CA4-8). Escala: $1 \mathrm{~mm}$. 
Remarks: The size of the $\mathrm{m} 1$ of Eucricetodon cf. gerandianus from CA1 is slightly larger than in the same element of E. gerandianus and E. longidens, less than in $E$. cetinensis and within the range of E. haslachensis, E. infralactorensis and E. aquitanicus. The robust mesoconid and the short mesolophid are typical of the populations of E. gerandianus of unit MN2, and very different from the other species of the genus Eucricetodon (Hugueney, 1999a).

Species: Eucricetodon aquitanicus Baudelot and de Bonis, 1968 (Fig. 4/11-15)

\section{Locality: Cuesta Agujeros 2 (CA2)}

Material: $3 \mathrm{~m} 1$ (CA2-2/36, CA2-2/37, CA2-2/40), $2 \mathrm{~m} 2$ (CA2-1, CA2-2/35), $1 \mathrm{~m} 3$ (CA2-2/34) and $2 \mathrm{M} 3$ (CA2-2/38, CA2-2/39).

Measurements: see Table 2.

\section{Description:}

$\mathrm{m} 1$ : Two cingulums that descend from the anteroconid connect with protoconid and metaconid, closing the anterosinusid and the protosinusid. The continuous anterolophulid connects the protoconid with the anteroconid. The metalophulid is anterior and connected to the anteroconid. The posterior branch of the metalophulid is short and not connected to the protoconid. Mesoconid thick. Labial posterolophid short or absent. Mesolophid short. Ectomesolophid present in one out of three specimens. Posterior branch of protoconid and hypoconid absent.

m2: Lingual anterolophid absent. Labial anterolophid connected to the base of the protoconid, closing the pro-

\begin{tabular}{llcccc}
\hline Element & Parameter & n & min. & mean & max. \\
\hline m1 & $L$ & 1 & - & 22.1 & - \\
& $W$ & 2 & 14.6 & 14.6 & 14.7 \\
$\mathrm{~m} 2$ & $L$ & 2 & 18.1 & 18.3 & 18.5 \\
& $W$ & 2 & 15.2 & 15.3 & 15.5 \\
$\mathrm{~m} 3$ & $L$ & - & - & - & - \\
& $W$ & 1 & - & 12.6 & - \\
$\mathrm{M} 3$ & $L$ & 2 & 12.8 & 13.1 & 13.4 \\
& $W$ & 2 & 11.8 & 12.4 & 12.9 \\
\hline
\end{tabular}

Table 2.- Measurements (in tenths of $\mathrm{mm}$ ) of the teeth of Eucricetodon aquitanicus from CA2. Abbreviations: L-Length; W-Width; m1-First lower molar; m2-Second lower molar; m3-Third lower molar; M3 - Third upper molar.

Tabla 2.- Medidas (en décimas de milímetro) de los dientes de Eucricetodon aquitanicus de CA2. Abreviaciones: L-Longitud; WAnchura; m1-Primer molar inferior; m2 - Segundo molar inferior; $\mathrm{m} 3$ - Tercer molar inferior; M3 - Tercer molar superior. tosinusid. Metalophulid slightly anterior. Sinusid directed backwards. Hypolophulid transverse or slightly anterior. Mesoconid thick. Mesolophid very short. Posterolophid high and closing the posterosinusid or descending towards the base of the entoconid, leaving the posterosinusid lingually open. In spite of the degree of wear, in one of the two specimens one can observe a short posterior branch of the hypoconid (CA2-2/35).

M3: Lingual anteroloph much reduced, almost nonexistent. Labial anteroloph long and united to the base of the paracone. Protolophule slightly anterior. Sinus reduced. Neo-entoloph high and narrow. Axioloph absent or very low. Mesoloph absent. Centroloph long and connected to the labial wall.

Species: Eucricetodon aff. aquitanicus Baudelot and de Bonis, 1968 (Fig. 3/3-4)

\section{Locality: Cabezo Carboneras 1 (CC1)}

Material and measurements (L $x W): 2 \mathrm{~m} 2$ (CC1-1, CC1-2) (17.51 x 14.77; x ).

\section{Description:}

m2: Lingual anterolophid absent. Metalophulid transverse (1) or directed backwards (1). Mesolophid very short. Sinusid directed backwards. Posterolophid high.

Remarks: The size of the molars of Eucricetodon aff. aquitanicus from CA2 is in the range of measurements of E. aquitanicus from Laugnac and E. infralactorensis from Estrepouy, the type-localities of these species, and is larger than in E. gerandianus. The length of the $\mathrm{m} 2$ of E. aff. aquitanicus from $\mathrm{CC} 1$ is slightly inferior to that from Laugnac and Estrepouy, while the width coincides with the lower values in these French populations.

The morphology of Eucricetodon from the Navarra localities here studied is characterized by a reduced (very short) mesolophid in the lower molars and the slightly oblique orientation of the crests. In the lineage E. collatus - E. infralactorensis a progressive change in the orientation of the crests has been observed (Hugueney, 1999a). The younger species present oblique crests (directed backwards), whereas they are transverse in the older ones. In the lower molars from CA2 and CC1, the metalophulid is more oblique than the hypolophulid, which is almost transverse. The strongly oblique orientation of the crests is more pronounced in the populations of $E$. infralactorensis from MN3. The reduction of the length of the mesolophids of the lower molars is very similar to what has been described in the populations of E. aquitanicus and E. infralactorensis of MN2 and MN3. Therefore, we assign this material from $\mathrm{CA} 2$ and $\mathrm{CC} 1$ to $E$. aff. aquitanicus. 


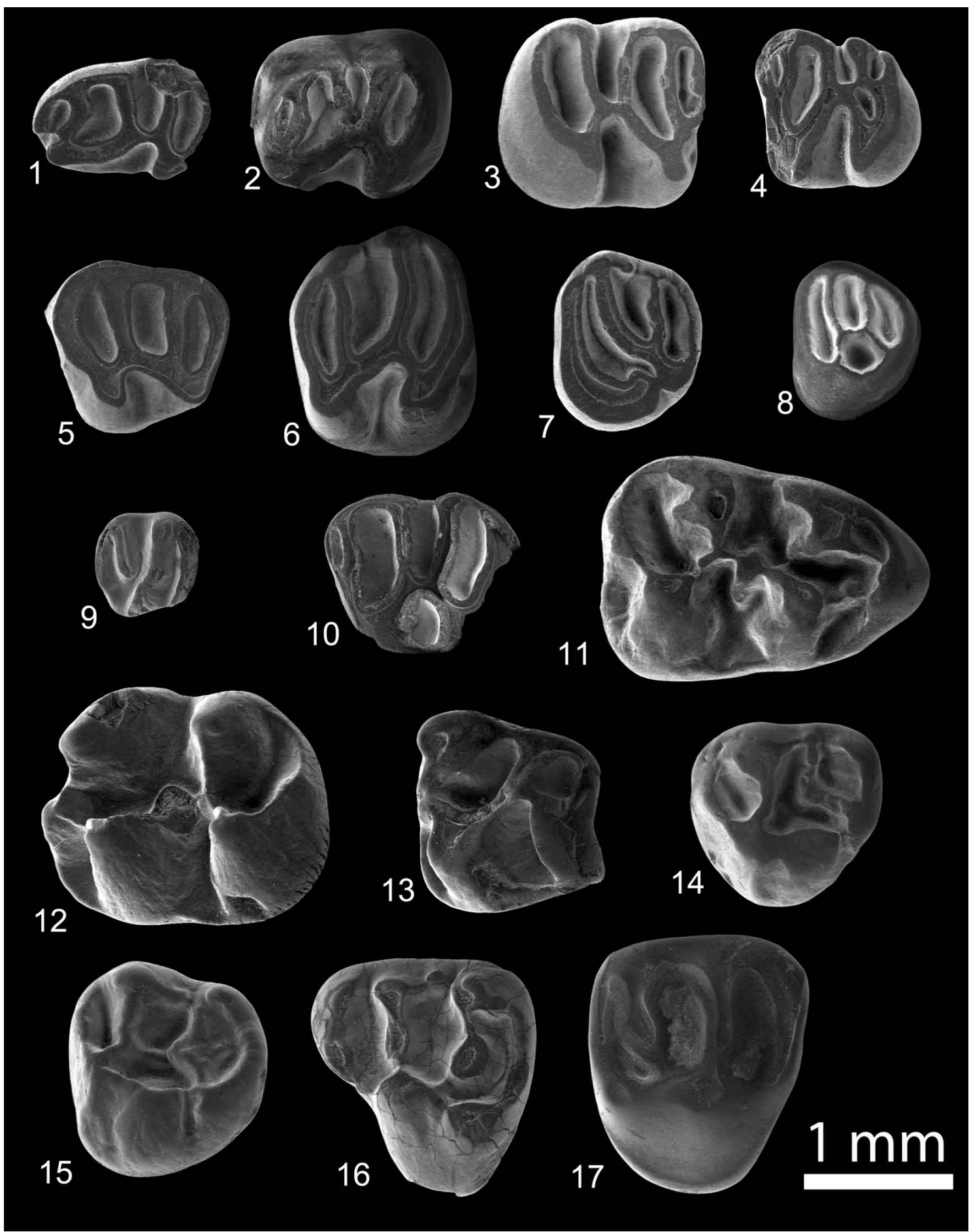

Fig. 4.- Ligerimys aff. magnus Álvarez-Sierra, 1988 from Cuesta Agujeros 4 (CA4). 1, d4 sin. (CA4-1/22); 2, p4 sin. (CA4-1/11); 3, m1,2 dext. (CA4-1/10); 4, m3 sin. (CA4-1/16); 5, D4 dext. (CA4-1/14); 6, M1 dext. (CA4-2); 7, M2 sin. (CA4-1/15); 8, M3 sin. (CA4-1/20); Eomyidae indet. from Cuesta Agujeros 2 (CA2). 9, M1 sin. (CA2-2/31); Pseudotheridomys sp. from Cuesta Agujeros 4 (CA4). 10, D4 dext. (CA4-1/12); Eucricetodon aquitanicus Baudelot and de Bonis, 1968 from Cuesta Agujeros 2 (CA2). 11, m1 dext. (CA2-2/36); 12, m2 sin. (CA2-1); 13, m3 sin. (CA2-2/34); 14, M3 sin. (CA2-2/38); 15, M3 sin. (CA2-2/39); Heteroxerus cf. paulhiacensis Black, 1965 from Cuesta Agujeros 2 (CA2). 16, D4 sin. (CA2-3/2); 17, P4 dext. (CA2-3/1). Scale: $1 \mathrm{~mm}$.

Fig. 4.- Ligerimys aff. magnus Álvarez-Sierra, 1988 de Cuesta Agujeros 4 (CA4). 1, d4 sin. (CA4-1/22); 2, p4 sin. (CA4-1/11); 3, m1,2 dext. (CA41/10); 4, m3 sin. (CA4-1/16); 5, D4 dext. (CA4-1/14); 6, M1 dext. (CA4-2); 7, M2 sin. (CA4-1/15); 8, M3 sin. (CA4-1/20); Eomyidae indet. de Cuesta Agujeros 2 (CA2). 9, M1 sin. (CA2-2/31); Pseudotheridomys sp. de Cuesta Agujeros 4 (CA4). 10, D4 dext. (CA4-1/12); Eucricetodon aquitanicus Baudelot and de Bonis, 1968 de Cuesta Agujeros 2 (CA2). 11, m1 dext. (CA2-2/36); 12, m2 sin. (CA2-1); 13, m3 sin. (CA2-2/34); 14, M3 sin. (CA2-2/38); 15, M3 sin. (CA2-2/39); Heteroxerus cf. paulhiacensis Black, 1965 de Cuesta Agujeros 2 (CA2). 16, D4 sin. (CA2-3/2); 17, P4 dext. (CA2-3/1). Escala: $1 \mathrm{~mm}$. 
Family: Gliridae Muirhead, 1819

Genus: Altomiramys Díaz Molina and López Martínez, 1979

Type species: Altomiramys daamsi Díaz Molina and López Martínez, 1979

Species: Altomiramys aff. daamsi Díaz Molina and López Martínez, 1979 (Fig. 5/1-5)

\section{Locality: Cuesta Agujeros 2 (CA2)}

Material and measurements (L $x \mathrm{~W}): 2 \mathrm{~m} 1$ (CA2-1/26, CA2-1/27) $(13.79 \times 13.40 ; 12.11 \times 12.71), 1 \mathrm{~m} 2$ (CA21/25) (13.75 x 13.88), 2 M1 (CA2-1/21, CA2-1/22) (12.53 x 13.44; 12.55 x ).

\section{Description:}

m1: Low-crowned teeth, with narrow crests and broad valleys. The anterolophid is long and very narrow, connected to the protoconid or isolated from it. Lingually, the metalophid joins the metaconid; labially it curves and is connected or not with the anterolophid. Centrolophid connected to the metaconid or not connected, short, or more than half the width of the tooth. The centrolophid forms a pronounced right angle with the metaconid complex. Mesolophid and posterolophid fuse into the entoconid. The mesolophid of one of the teeth presents a small posterior spur. Posterotropid of medium length or absent.

$\mathrm{m} 2$ : Low-crowned teeth, with narrow crests and broad valleys. Anterolophid not connected to the protoconid. The centrolophid is short (not more than $1 / 4$ of the width of the tooth) and forms a right angle with the metaconid complex. Mesolophid and posterolophid fuse into the entoconid. Accessory crests absent.

M1: Anteroloph isolated from the protocone and lower than that cusp. There is only one precentroloph, of medium length, connected to the paracone. Protoloph and metaloph connect at the lingual border to the protocone, forming an oblique Y. Posteroloph low connected to the protocone.

Remarks: The species Altamiromys daamsi was described on the basis of a single specimen in the locality of Loranca (upper part of unit MN2) (Díaz-Molina and López-Martínez, 1979). Daams (1989) enlarged the scarce knowledge of this species, describing a population from the locality of Ramblar 1 (Lower Ramblian). Daams (1999) cited the presence of unpublished material of this genus, which shows important similarities with Peridyromys murinus, in Spanish localities of unit MN1 and the lower part of MN2. Since then, no other record of this genus was published.

The size of the material from CA2 is somewhat different from the material described by Daams (1989) from Ram- blar 1. In CA2, the length of $\mathrm{m} 1,2$ is somewhat smaller than in Loranca and Ramblar 1, whereas the width is similar to the $\mathrm{m} 2$ from Ramblar 1 and quite larger than the $\mathrm{m} 1$ from that locality. The size of the M1 from CA2 is clearly smaller than in Loranca and Ramblar 1.

The low crown, narrow crests and wide valleys are diagnostic characters of the genus Altomiramys. However, the material from CA2 shows some important differences, apart from size. One of these differences is the development of a short posterior spur on the middle of the mesolophid of one of the two m1 (Fig. 5/2). Another difference is the presence of a posterotropid in one of the two $\mathrm{m} 1$ (Fig. 5/1), characters not present in the population from Ramblar 1. The morphology of the $\mathrm{m} 2$ from CA2 is similar to the material from Ramblar 1, although the shape is more quadrate in CA2 (13.75 x 13.88) than in Ramblar 1, where it is subrectangular (14.10 x 13.10). The absence of the endoloph, the presence of an anteroloph with a lingual end that is much lower than the protocone, and the development of a precentroloph of medium length in the M1 of the Altomiramys from CA2 is very similar to what was described for $A$. daamsi. However, while in the M1 from CA2 the anteroloph is connected to the base of the paracone and the posteroloph to the base of the metacone, the two M1 of Ramblar 1 do not show this kind of connections.

Daams (1989) considered the material of Pseudodryomys simplicidens from Cetina de Aragón (Daams, 1974) to represent Altomiramys aff. daamsi. In that association, Daams (1989) observed, among other things, that $23 \%$ of the $\mathrm{m} 1,2$ lack accessory crests, and $23 \%$ of the M1,2 only have a precentroloph, concluding that these specimens belong to Altomiramys aff. daamsi.

The material of Altomiramys from CA2 differs from $A$. daamsi from Loranca and Ramblar 1 and coincides greatly with the description by Daams (1989) of Altomiramys aff. daamsi from Cetina de Aragón. Therefore, until more material is available, we classify this material as $A$. aff. daamsi.

Species: Altomiramys sp.

(Fig. 5/6)

\section{Locality: Cuesta Agujeros 4 (CA4)}

Material and measurements (L $x W)$ : 1 M2 (CA4-1/3) ( x 14.93).

\section{Description:}

M2: Crests are narrow and well separated. Anteroloph long, connected to the paracone and not connected to the protocone. Protoloph continuous and connected to the paracone. The lingual portion of the protoloph is longitu- 

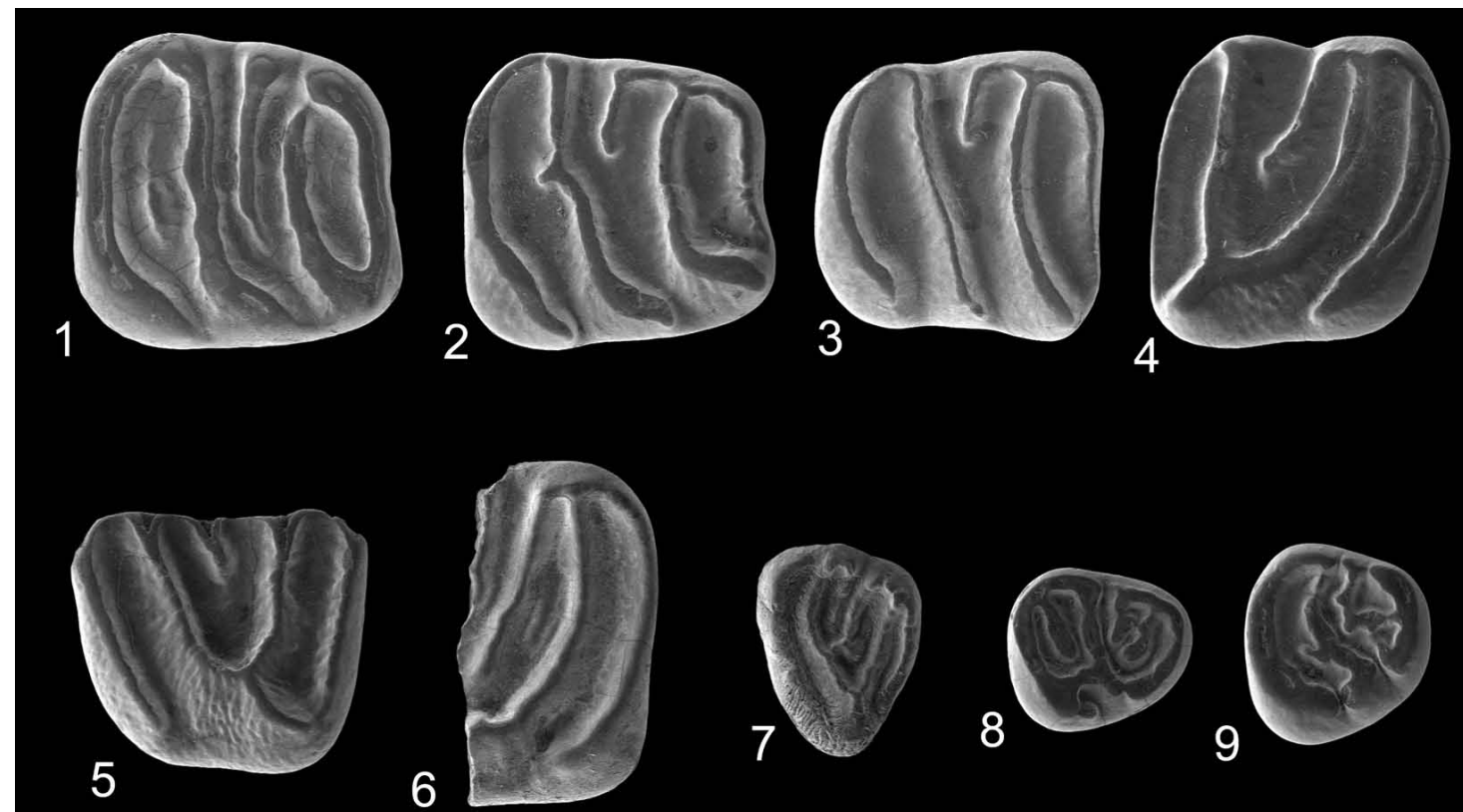

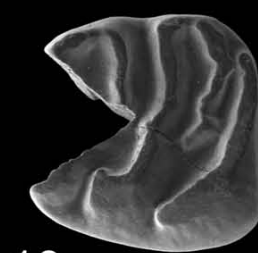

10
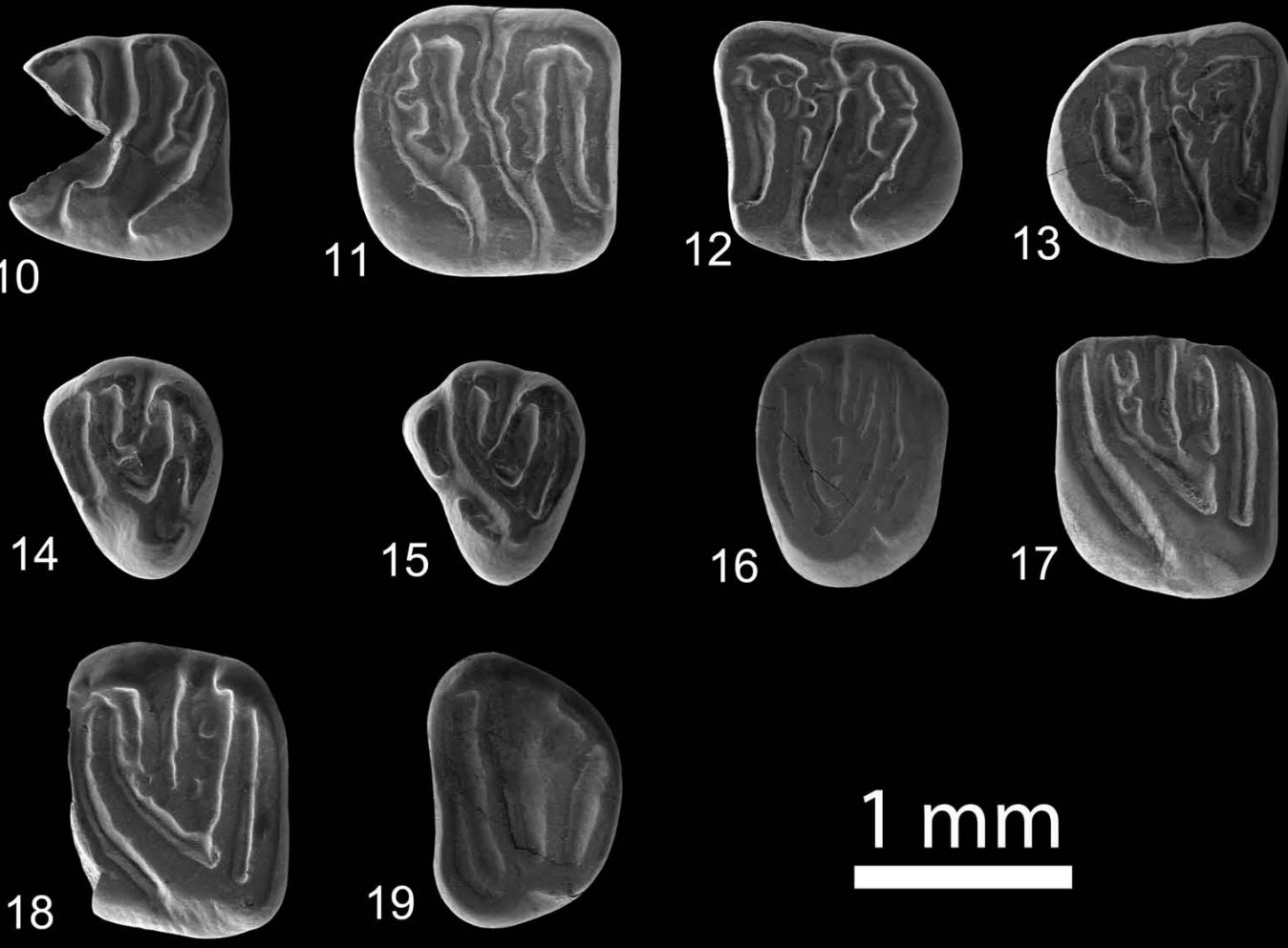
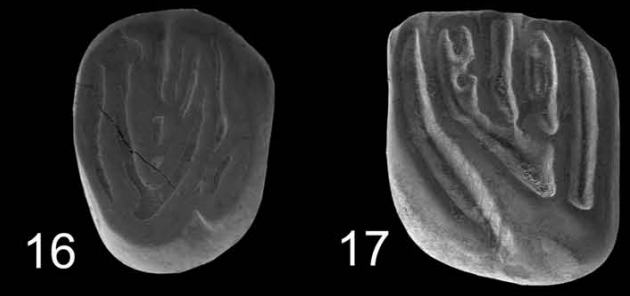

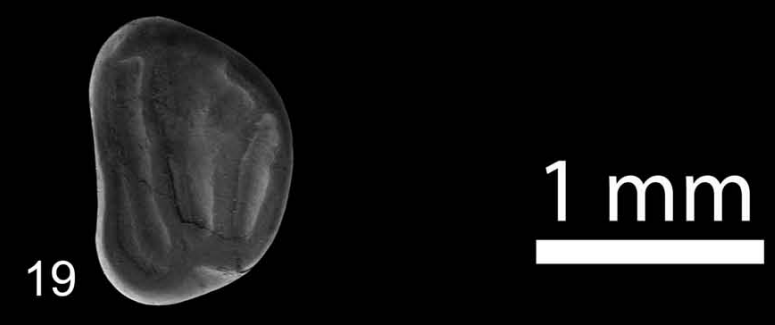

Fig. 5.- Altomiramys aff. daamsi Díaz Molina and López Martínez, 1979 from Cuesta Agujeros 2 (CA2). 1, m1 dext. (CA2-1/26); 2, m1 dext. (CA2-1/27); 3, m2 dext. (CA2-1/25); 4, M1 dext. (CA2-1/21); 5, M1 sin. (CA2-1/22); Altomiramys sp. from Cuesta Agujeros 4 (CA4). 6, M2 dext. (CA4-1/3); cf. Vasseuromys sp. from Cuesta Agujeros 2 (CA2). 7, D4 sin. (CA2-2/22); Peridyromys turbatus Álvarez et al., 1990 from Cuesta Agujeros 2 (CA2). 8, d4 dext. (CA2-2/21); 9, p4 dext. (CA2-2/23); 10, m1 sin. (CA2-2/30); 11, m2 dext. (CA2-1/24); 12, m3 sin. (CA21/30); 13, m3 dext. (CA2-1/32); 14, D4 sin. (CA2-1/17); 15, D4 sin. (CA2-2/18); 16, P4 dext. (CA2-1/19); 17, M1 sin. (CA2-1/29); 18, M2 sin. (CA2-1/23); 19, M3 sin. (CA2-1/31). Scale: $1 \mathrm{~mm}$.

Fig. 5.- Altomiramys aff. daamsi Díaz Molina and López Martínez, 1979 de Cuesta Agujeros 2 (CA2). 1, m1 dext. (CA2-1/26); 2, m1 dext. (CA21/27); 3, m2 dext. (CA2-1/25); 4, M1 dext. (CA2-1/21); 5, M1 sin. (CA2-1/22); Altomiramys sp. de Cuesta Agujeros 4 (CA4). 6, M2 dext. (CA41/3); cf. Vasseuromys sp. de Cuesta Agujeros 2 (CA2). 7, D4 sin. (CA2-2/22); Peridyromys turbatus Álvarez et al., 1990 de Cuesta Agujeros 2 (CA2). 8, d4 dext. (CA2-2/21); 9, p4 dext. (CA2-2/23); 10, m1 sin. (CA2-2/30); 11, m2 dext. (CA2-1/24); 12, m3 sin. (CA2-1/30); 13, m3 dext. (CA2-1/32); 14, D4 sin. (CA2-1/17); 15, D4 sin. (CA2-2/18); 16, P4 dext. (CA2-1/19); 17, M1 sin. (CA2-1/29); 18, M2 sin. (CA2-1/23); 19, $\mathrm{M} 3 \mathrm{sin}$. (CA2-1/31). Escala: $1 \mathrm{~mm}$. 
dinal, parallel to the lingual border. Precentroloph long. Between protoloph and precentroloph a short prototrope is present.

Remarks: One of the striking morphological characters of this specimen is the small width of the crests, a morphology that is typical of the genus Altomiramys (Díaz Molina and López-Martínez, 1979; Daams, 1989; Daams, 1999). The original diagnosis of the genus gives as diagnostic character the presence of a single centroloph (precentroloph). In Ramblar 1, Daams (1989) confirmed this character in the M1 and described a second centroloph (postcentroloph) in the M2. Apart from the presence of this second centroloph, Daams (1989) described in some of the M2 from Ramblar 1 the existence of a small accessory crest, which would be the prototrope according to the nomenclature of Freudenthal (2004), used in this work.

The specimen CA4-1/3 is broken. Therefore, it is difficult to know whether it is a M1 or a M2. However, the lingual end of the protoloph shows a change of orientation, from oblique to longitudinal (Fig. 5/6), which is typical of the M2 of the majority of representatives of the family Gliridae. In the posterior part of this specimen a short postcentroloph seems to be present (Fig. 5/6).

The presence of widely separated narrow crests, of a long precentroloph, a short prototrope and of a possible postcentroloph in this M2 permit to refer this fragment to the genus Altomiramys.

Until now, the genus Altomiramys had been recognized in localities of the Iberian Peninsula in the interval between unit MN1 and the lower part of unit MN3 (local zone Z). The accompanying fauna in CA4 (Pseudotheridomys sp., Ligerimys aff. magnus and Armantomys cf.jasperi) permits to attribute this locality to the Upper Ramblian (local zone A, MN3), which constitutes an upward extension of its range.

Genus: Peridyromys Stehlin and Schaub, 1951

Type species: Peridyromys murinus (Pomel, 1853)

Species: Peridyromys murinus (Pomel, 1853)

(Fig. 6/1)

\section{Locality: Cuesta Agujeros 3 (CA3)}

Material and measurements (Lx W): $1 \mathrm{~d} 4$ (CA3-1/8)

(7.33 x 6.18), 3 M1,2 (CA3-1/3, CA3-1/5, CA3-1/6)

$(9.78 \times 10.82 ; 9.18 \times 9.80 ; 9.39 \times)$.

\section{Description:}

d4: Narrower anteriorly than posteriorly. The anterior valley presents two parallel crests. The posterior valley is closed. Posterotropid absent.
M1,2: Anteroloph long and not connected to protocone or paracone. Protoloph long and oblique, connected to the metaloph in Y-pattern. Pre- and postcentroloph present. Precentroloph longer than postcentroloph. Metaloph transverse. Posteroloph connected to the metacone or not connected.

Remarks: In size, the material of Peridyromys murinus from CA3 is very similar to other populations (ÁlvarezSierra et al., 1990; Murelaga, 2000; Murelaga et al., 2004a). The development of a complete pre- and postcentroloph in the M1,2 from CA3 coincides with morphotype C described by Daams (1981). This morphotype is dominant (between $60 \%$ in La Galocha 5 and $76 \%$ in Santa Cilia) in the M1,2 of Iberian populations of $P$. murinus.

Species: cf. Peridyromys murinus (Pomel, 1853)

(Fig. 6/2)

Locality: Cuesta Agujeros 4 (CA4)

Material and measurements (L $x W)$ : 1 M3 (CA4-1/2) (6.86 x 8.85).

\section{Description:}

M3: Endoloph continuous. Anteroloph and protoloph connected to the paracone. Precentroloph of medium length. Postcentroloph absent. Posteroloph short and separated from the metacone by a narrow groove.

Remarks: The small size of this specimen, the presence of a single centroloph (precentroloph) of medium length and the degree of connection between anteroloph and protocone in the M3 of CA4 are characteristic of $P$. murinus from the Lower Miocene.

Species: Peridyromys turbatus Álvarez et al., 1990

(Fig. 5/8-19)

Locality: Cuesta Agujeros 2 (CA2)

Material: 3 d4 (CA2-6, CA2-2/21, CA2-2/26), 3 p4 (CA2-1/44, CA2-2/23, CA2-2/29), 1 m1 (CA2-2/30), 2 m2 (CA2-1/24, CA2-2/14), 3 m3 (CA2-1/30, CA2-1/32, CA2-2/11), 3 D4 (CA2-1/16, CA2-1/17, CA2-2/18), 1 P4 (CA2-1/19), 2 M1 (CA2-1/29, CA2-2/7), 1 M2 (CA21/23), 2 M3 (CA2-1/31, CA2-2/17).

Measurements: see Table 3.

Description:

d4: Narrower anteriorly than posteriorly. The anterior valley presents two small parallel crests that run from the lingual border almost to the labial border, and which are connected halfway. The posterior valley is closed and presents a long posterotropid, connected to the entoconid. 


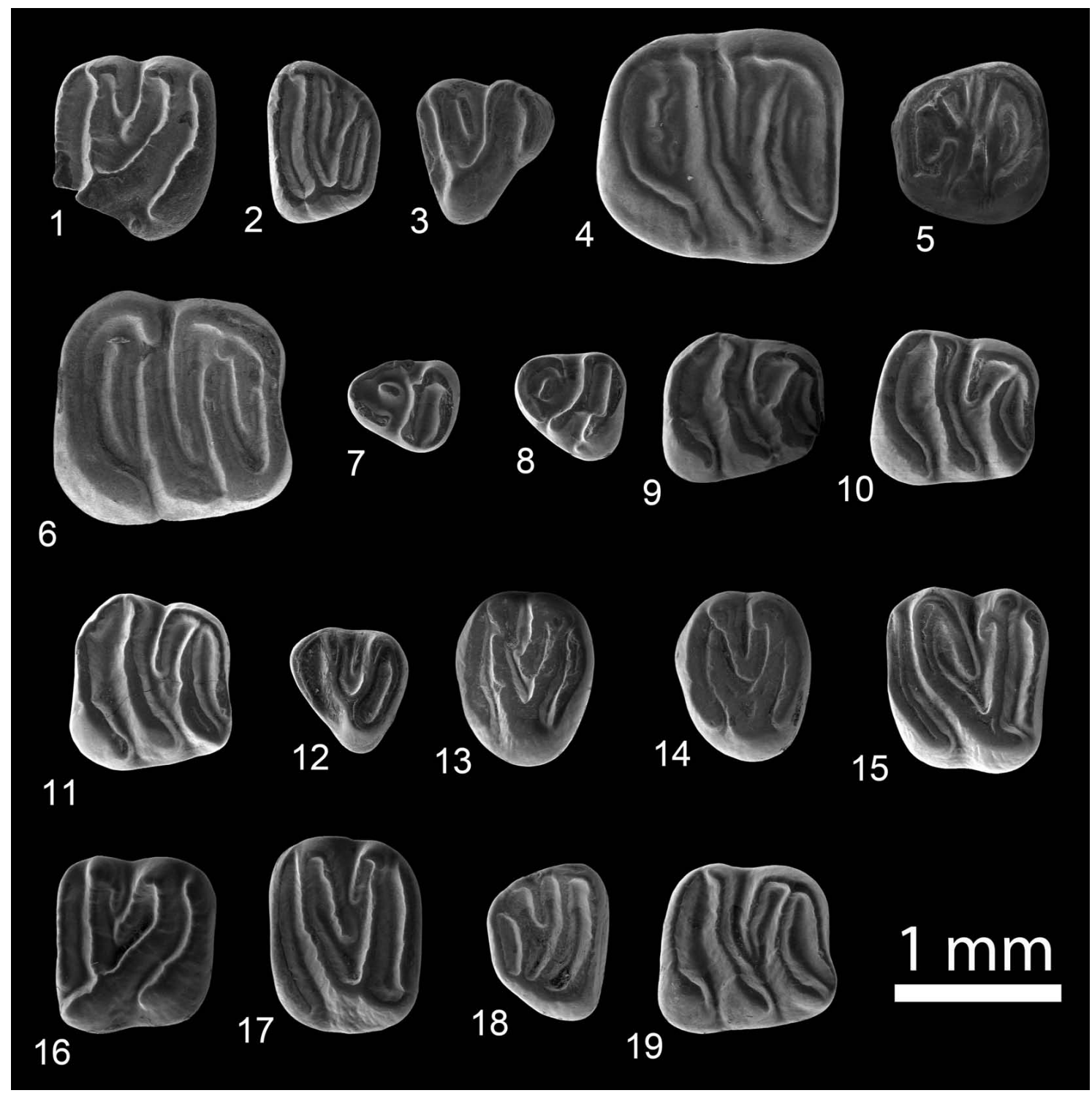

Fig. 6.- Peridyromys murinus (Pomel, 1853) from Cuesta Agujeros 3 (CA3). 1, M1 dext. (CA3-1/3); cf. Peridyromys murinus from Cuesta Agujeros 4 (CA4). 2, M3 sin. (CA4-1/2); cf. Prodryomys sp. from Cuesta Agujeros 2 (CA2). 3, D4 dext. (CA2-2/19); Prodryomys cf. brailloni (Thaler, 1966) from Cuesta Agujeros 3B (CA3B). 4, m2 dext. (CA3B-1); Prodryomys cf. brailloni from Cuesta Agujeros 4 (CA4). 5, p4 sin. (CA4-4); 6, m1 dext. (CA4-1/1); Simplomys aff. aljaphi Hugueney et al. 1978 from Cuesta Agujeros 2 (CA2). 7, d4 dext. (CA2-2/28); 8, p4 sin. (CA22/25); 9, $\mathrm{m} 1$ dext. (CA2-1/36); 10, $\mathrm{m} 1$ dext. (CA2-1/37); 11, m2 dext. (CA2-1/40); 12, D4 sin. (CA2-2/20); 13, P4 sin. (CA2-1/18); 14, P4 sin. (CA2-1/20); 15, M1 sin. (CA2-1/34); 16, M1 dext. (CA2-1/35); 17, M2 sin. (CA2-1/33); 18, M3 dext. (CA2-2/16); 19, m2 dext. (CA2-1/39). Scale: $1 \mathrm{~mm}$.

Fig. 6.- Peridyromys murinus (Pomel, 1853) de Cuesta Agujeros 3 (CA3). 1, M1 dext. (CA3-1/3); cf. Peridyromys murinus de Cuesta Agujeros 4 (CA4). 2, M3 sin. (CA4-1/2); cf. Prodryomys sp. de Cuesta Agujeros 2 (CA2). 3, D4 dext. (CA2-2/19); Prodryomys cf. brailloni (Thaler, 1966) de Cuesta Agujeros 3B (CA3B). 4, m2 dext. (CA3B-1); Prodryomys cf. brailloni de Cuesta Agujeros 4 (CA4). 5, p4 sin. (CA4-4); 6, m1 dext. (CA4-1/1); Simplomys aff. aljaphi Hugueney et al., 1978 de Cuesta Agujeros 2 (CA2). 7, d4 dext. (CA2-2/28); 8, p4 sin. (CA2-2/25); 9, m1 dext. (CA2-1/36); 10, m1 dext. (CA2-1/37); 11, m2 dext. (CA2-1/40); 12, D4 sin. (CA2-2/20); 13, P4 sin. (CA2-1/18); 14, P4 sin. (CA2-1/20); 15, M1 sin. (CA2-1/34); 16, M1 dext. (CA2-1/35); 17, M2 sin. (CA2-1/33); 18, M3 dext. (CA2-2/16); 19, m2 dext. (CA2-1/39). Escala: 1 mm.

p4: The configuration of the crests in the anterior part is chaotic. The posterior part is formed by the mesolophid and the posterolophid that close the posterior valley lingually. In two of the three specimens, the middle part of the mesolophid develops a short posterior spur, possibly related with the posterotropid. In two of the three specimens, a posterotropid, which is continuous or formed by two smalls cusps, is present in the posterior valley.

$\mathrm{m} 1$ : The only specimen is broken anteriorly. Centrolophid of medium length. There is no connection of the metalophid with the metaconid. Mesolophid somewhat sinuous. Mesolophid and posterolophid connected to the entoconid. From the entoconid a sinuous posterotropid reaches the middle of the tooth. 


\begin{tabular}{|c|c|c|c|c|c|}
\hline Element & Parameter & $\mathrm{n}$ & $\min$. & mean & $\max$. \\
\hline \multirow[t]{2}{*}{$\mathrm{d} 4$} & $L$ & 1 & - & 7.11 & - \\
\hline & $W$ & 2 & 6.14 & & 6.84 \\
\hline \multirow[t]{2}{*}{ p4 } & $L$ & 3 & 7.99 & 8.29 & 8.83 \\
\hline & $W$ & 3 & 7.53 & 8.20 & 8.61 \\
\hline \multirow[t]{2}{*}{$\mathrm{m} 1$} & $L$ & 0 & - & - & - \\
\hline & $W$ & 1 & - & 9.96 & - \\
\hline \multirow[t]{2}{*}{$\mathrm{m} 2$} & $L$ & 2 & 11.75 & 11.79 & 11.82 \\
\hline & $W$ & 1 & - & 12.03 & - \\
\hline \multirow[t]{2}{*}{$\mathrm{m} 3$} & $L$ & 3 & 10.56 & 10.84 & 11.24 \\
\hline & $W$ & 3 & 10.24 & 10.38 & 10.67 \\
\hline \multirow[t]{2}{*}{ D4 } & $L$ & 3 & 8.18 & 8.69 & 9.09 \\
\hline & $W$ & 3 & 9.63 & 9.81 & 10.06 \\
\hline \multirow[t]{2}{*}{ P4 } & $L$ & 1 & - & 7.93 & - \\
\hline & $W$ & 1 & - & 11.23 & - \\
\hline \multirow[t]{2}{*}{ M1 } & $L$ & 2 & 9.87 & 10.10 & 10.32 \\
\hline & $W$ & 2 & 12.06 & 12.71 & 13.35 \\
\hline \multirow[t]{2}{*}{ M2 } & $L$ & 0 & - & - & - \\
\hline & $W$ & 1 & - & 13.20 & - \\
\hline \multirow[t]{2}{*}{ M3 } & $L$ & 2 & 6.77 & 7.41 & 8.05 \\
\hline & $W$ & 2 & 9.37 & 10.48 & 11.58 \\
\hline
\end{tabular}

Table 3.- Measurements (in tenths of $\mathrm{mm}$ ) of the teeth of Peridyromys turbatus Álvarez et al., 1990 from CA2. Abbreviations: L-Length; W-Width; d4-Fourth lower decidual; p4 Fourth lower premolar; m1-First lower molar; m2-Second lower molar; m3 - Third lower molar; D4 - Fourth upper decidual; P4-Fourth upper premolar; M1-First upper molar; M2-Second upper molar; M3 - Third upper molar.

Tabla 3.- Medidas (en décimas de milímetro) de los dientes de Peridyromys turbatus Álvarez et al., 1990 de CA2. Abreviaciones: L-Longitud; W-Anchura; d4-Cuarto decidual inferior; p4-Cuarto premolar inferior; m1-Primer molar inferior; $\mathrm{m} 2$ - Segundo molar inferior; $\mathrm{m} 3$ - Tercer molar inferior; D4 - Cuarto decidual superior; P4 - Cuarto premolar superior; M1 - Primer molar superior; M2 - Segundo molar superior; M3 - Tercer molar superior.

$\mathrm{m} 2$ : Anterolophid and metalophid not connected to protoconid and entoconid, respectively. Centrolophid sinuous, medium-long, not reaching the labial border. One specimen has a small accessory crest in the central valley. In the other specimen, two small accessory crests in the central valley are connected to the centrolophid. Mesolophid and posterolophid connected to the entoconid. In one of the specimens, the mesolophid has a small posterior spur (Fig. 5/11). Posterotropid sinuous and of medium length, not connected to the entoconid or connected (Fig. $5 / 11$ ). In this latter specimen the posterotropid presents two short posterior spurs, one of which is low connected to the posterolophid.

m3: Anterolophid not connected to the protoconid. Metalophid not connected to the metaconid and with a chaotic configuration. In all the specimens, the centrolophid is of medium length with several connections to the chaotic lingual part of the metalophid and to its continuous labial part. Mesolophid sinuous, continuous (1) (Fig. 5/13) or interrupted (2) (Fig. 5/12), and generally connected to the entoconid. Posterolophid connected to the entoconid. Posterotropid sinuous and medium-long. In one of the three specimens, the posterotropid is connected labially to the mesolophid and has a posterolingual spur, connected to the posterolophid (Fig. 5/12).

D4: Anteroloph of medium length or long, continuous (Fig. 5/14) or interrupted (Fig. 5/15), connected or not to paracone and protocone. Pre- and postcentroloph present in all specimens; the postcentroloph is longer than the precentroloph, connected to the protoloph. The precentroloph in two of the three specimens is connected to the postcentroloph. Posteroloph continuous (1) (Fig. 5/15) or interrupted (2) (Fig. 5/14), connected (2) to the metacone or not connected (1), and isolated (2) (Fig. 5/14) or not (1) (Fig. 5/15) from the protocone.

P4: Anteroloph long, separated from protocone and paracone by a narrow groove. Pre- and postcentroloph present and connected to paracone and metacone, respectively. The postcentroloph is longer than the precentroloph and these crests are interconnected in two points. Posteroloph well developed.

M1: Endoloph absent. Protocone strongly displaced towards the posterolingual border. Pre- and postcentroloph present. Prototrope present in both specimens; metatrope present in one of the two. The centrolophs connect at their lingual end. The postcentroloph is curved and connected to the completely transverse metaloph. Posteroloph high and connected to the protocone.

M2: Endoloph absent. Protoloph not connected to the paracone. Pre- and postcentroloph present. The precentroloph is connected to the paracone and the postcentroloph not connected to the metacone. Prototrope of medium length. Metatrope medium-long, with several connections to the postcentroloph, in a chaotic way. Metaloph slightly oblique. Posteroloph connected to the protocone and separated from the metacone by a narrow groove.

M3: Endoloph present. Anteroloph and protoloph connected to the paracone. Precentroloph short. Postcentroloph long, with a curved lingual end and connected to the metaloph. Posteroloph of medium length, connected to the metaloph.

Remarks: The species Peridyromys turbatus was first described from the locality of San Juan (Álvarez-Sierra et al., 1990). The size of $P$. turbatus from CA2 is very simi- 
lar to that from the type-locality, and clearly larger than P. murinus. Only the M3 from CA2 is somewhat smaller than that of $P$. murinus.

The lower dentition of Peridyromys turbatus from CA2 is very similar to that from the type-locality, San Juan. Some morphological characters, however, are different: The centrolophid of the $\mathrm{m} 3$ from CA2 is more continuous than in the material from San Juan. In P. turbatus from San Juan, the metalophid and centrolophid are discontinuous; in CA2 that morphology is only present in the metalophid, whereas the centrolophid is continuous.

The upper molars from CA2 are very similar to those from the type-locality. Only the M3 from CA2 has a more simple pattern than in San Juan. In San Juan more than $90 \%$ of the specimens have an accessory crest, the single specimen from CA2 does not have one.

The only differences between the populations of Peridyromys turbatus from San Juan and CA2 are observed in the D4 and P4: the D4 from CA2 has pre- and postcentroloph connected, and a posteroloph not connected to the protocone in two out of three specimens; in the P4 from CA2 there are two connections between the centrolophs, whereas there is only one connection in D4 and P4 from San Juan.

The chaotic pattern of the crests, the oblique trigone of the M1 and the absence of accessory crests between the centrolophs of the upper molars of the population from CA2, distinguish this material clearly from Peridyromys jaegeri and $P$. aquatilis. The size and general morphology of the material from CA2 is clearly distinct from $P$. murinus.

The slight differences observed between the populations from CA2 and San Juan don't appear to be relevant at species level. We refer this material to P. turbatus.

Genus: Prodryomys Mayr, 1979

Type species: Prodryomys satus Mayr, 1979

Species: cf. Prodryomys sp.

(Fig. 6/3)

Locality: Cuesta Agujeros 2 (CA2)

Material and measurements (L $x W)$ : 2 D4 (CA2-2/19, CA2-2/27) (7.49 x 8.63;x).

\section{Description:}

D4: Anteroloph of medium length, isolated from the protocone and connected to the paracone. Postcentroloph of medium length and connected to the metacone. Posteroloph long, lingually low, connected to the metacone and the protocone at low or high level.

Remarks: The morphology of the anteroloph and the degree of development of the centrolophs is similar to the
D4 of Peridyromys (Prodryomys) brailloni from La Galocha 5 (Álvarez-Sierra et al., 1990). On the other hand, the general morphology of this specimen is very different from the other D4 from CA2.

Species: Prodryomys cf. brailloni (Thaler, 1966)

(Fig. 6/4-6)

Locality: Cuesta Agujeros 3B (CA3B)

Material and measurements ( $L \times W): 1 \mathrm{~m} 2$ (CA3B-1) (14.31 x 13.40).

\section{Description:}

m2: Anterolophid connected to the protoconid. Metalophid connected to the protoconid and to the base of the metaconid. The metalophid surpasses the middle of the tooth. Mesolophid and posterolophid continuous and connected to the entoconid. Two accessory crests are present, an anterotropid of medium length and a mediumlong posterotropid.

Remarks: The general morphology and the size of the $\mathrm{m} 2$ from CA3B-1 are very similar to those of the populations of Prodryomys brailloni from MN3. The size of this scarce material is clearly smaller than that of other species of the genus ( $P$. gregarius and $P$. remmerti) and larger than P. satus.

Morphologically, the single available molar from CA3B presents broad and shallow valleys and two accessory crests, one in the anterior valley (anterotropid) and one in the posterior valley (posterotropid). The development of these accessory crests is very similar to those described from Bouzigues, type-locality of $P$. brailloni (Thaler, 1966; Aguilar, 1974) and La Galocha 5 (Ebro Basin, MN3; Álvarez-Sierra et al., 1990).

\section{Locality: Cuesta Agujeros 4 (CA4)}

Material and measurements ( $L x W): 1 \mathrm{p} 4$ (CA4-4) (9.45 x 9.36), $1 \mathrm{~m} 1$ (CA4-1/1) (14.05 x 13.38), 1 M1,2 (CA4-1/5) ( x ).

\section{Description:}

p4: Anterolophid connected to the protoconid. Metalophid not continuous and connected to protoconid and metaconid. The metaconid gives rise to a short centrolophid. Mesolophid and posterolophid continuous and connected to the entoconid. Posterotropid long.

$\mathrm{m} 1$ : Anterolophid connected to the protoconid. Metalophid connected to the protoconid and separated from the metaconid. Anterotropid long and connected to the metalophid at its lingual end. Centrolophid long and free, not reaching the labial border. Mesolophid interrupted near the lingual border. Posterolophid thick and connected to the entoconid. Posterotropid long. 
M1,2: Only the anterolabial part is preserved. The anterior valley is wide and shallow. Anteroloph connected to the paracone at medium height. In the central valley there are two centrolophs.

Remarks: The general morphology and the size of this material is very similar to Prodryomys brailloni, described by Álvarez-Sierra et al. (1990) from the localities of La Galocha 5 and San Juan.

Prodryomys from CA4 has brachyodont molars with broad and shallow valleys, and thick crests. The presence in $\mathrm{m} 1$ of a metalophid that is not connected to the metaconid reminds one of Peridyromys, but the much larger size of the material from CA4 distinguishes it clearly from the species of that genus from the Lower Miocene.

The scarce material available of this taxon impedes a precise determination.

Genus: Simplomys García-Paredes, 2009 (in GarcíaParedes et al. 2009)

Type species: Pseudodryomys simplicidens de Bruijn, 1966

Species: Simplomys aff. aljaphi (Hugueney et al. 1978) (Fig. 6/7-19)

Locality: Cuesta Agujeros 2 (CA2)

Material: 1 d4 (CA2-2/28), 1 p4 (CA2-2/25), 3 m1 (CA2-1/36, CA2-1/37, CA2-1/38), 3 m2 (CA2-1/39, CA2-1/40, CA2-1/41), 1 D4 (CA2-2/20), 2 P4 (CA21/18, CA2-1/20), 4 M1 (CA2-2, CA2-1/34, CA2-1/35, CA2-2/12), 2 M2 (CA2-1/33, CA2-2/13), 1 M3 (CA2$2 / 16)$.

Measurements: see Table 4.

\section{Description:}

d4: Tooth with suboval outline and a very simple crest pattern. The anterior part is formed by a continuous crest that runs from the lingual border, near the base of the entoconid to close to the mesoconid. In the center of the anterior valley a small crest/cusp is present. Mesolophid and posterolophid enclose a posterior valley without accessory crests.

p4: Tooth with suboval contour and a little concave. The reduced anterior part is formed by a curved crest with a labial spur that appears to be the metalophid. The mesolophid is longer than the posterolophid, connected to the latter near the labial border, thus dividing the posterior valley into a large lingual part and a smaller labial part.

m1: Teeth with subrectangular outline. Anterolophid short and not connected to the protoconid. Centrolophid curved and long; in two specimens it reaches the middle of the tooth (Fig. 6/10), and in one it is longer (Fig. 6/9),

\begin{tabular}{lllccc}
\hline Element & Parameter & $\mathrm{n}$ & min. & mean & max. \\
\hline $\mathrm{d} 4$ & $L$ & 1 & - & 6.02 & - \\
& $W$ & 1 & - & 5.46 & - \\
$\mathrm{p} 4$ & $L$ & 1 & - & 6.25 & - \\
& $W$ & 1 & - & 6.16 & - \\
$\mathrm{m} 1$ & $L$ & 3 & 8.83 & 9.30 & 9.55 \\
& $W$ & 3 & 8.32 & 8.74 & 8.96 \\
$\mathrm{~m} 2$ & $L$ & 3 & 9.59 & 9.75 & 9.84 \\
& $W$ & 3 & 8.97 & 9.65 & 10.36 \\
$\mathrm{D} 4$ & $L$ & 1 & - & 6.71 & - \\
& $W$ & 1 & - & 7.12 & - \\
$\mathrm{P} 4$ & $L$ & 2 & 8.27 & 8.46 & 8.64 \\
& $W$ & 2 & 9.82 & 9.92 & 10.01 \\
$\mathrm{M} 1$ & $L$ & 4 & 8.50 & 9.04 & 9.27 \\
& $W$ & 4 & 10.24 & 10.47 & 10.68 \\
M2 & $L$ & 1 & - & 8.92 & - \\
& $W$ & 1 & - & 11.40 & - \\
M3 & $L$ & 1 & - & 6.54 & - \\
& $W$ & 1 & - & 9.01 & - \\
\hline
\end{tabular}

Table 4.- Measurements (in tenths of $\mathrm{mm}$ ) of the teeth of Simplomys aff. aljaphi Hugueney et al. 1978 from CA2. Abbreviations: L-Length; W-Width; d4-Fourth lower decidual; p4-Fourth lower premolar; m1-First lower molar; m2-Second lower molar; D4-Fourth upper decidual; P4-Fourth upper premolar; M1-First upper molar; M2 - Second upper molar; M3 - Third upper molar.

Tabla 4.- Medidas (en décimas de milímetro) de los dientes de Simplomys aff. aljaphi Hugueney et al., 1978 de CA2. Abreviaciones: L-Longitud; W-Anchura; d4-Cuarto decidual inferior; $\mathrm{p} 4$ - Cuarto premolar inferior; m1-Primer molar inferior; m2 - Segundo molar inferior; D4Cuarto decidual superior; P4-Cuarto premolar superior; M1-Primer molar superior; M2 - Segundo molar superior; M3 - Tercer molar superior.

connecting to the metalophid near the labial border of the tooth. Mesolophid and posterolophid long and connected to the entoconid.

m2: Subquadrangular. Anterolophid not connected to the protoconid. Centrolophid curved and long, reaching beyond the middle of the tooth. In two of the three specimens the labial end of the centrolophid is low connected to the metalophid. Mesolophid long and connected to the entoconid. Posterolophid long and connected to the entoconid at mid-height. In one of the three specimens, there are two tiny, low accessory crests, one between centrolophid and mesolophid and another one (posterotropid) in the posterior valley.

D4: Anteroloph of medium length, connected to the paracone. Protoloph and metaloph of equal length, united 
in a Y-shape. Postcentroloph low and of medium length. Posteroloph long and connected to protocone and paracone.

P4: Teeth of suboval contour. Anteroloph long and not connected to protocone or paracone. Protoloph and metaloph united to the protocone in a $\mathrm{V}$-shape. In one specimen (Fig. 6/15), pre- and postcentroloph are large and united in the central valley. In the other one (Fig. 6/14), the precentroloph is short and the postcentroloph long and they are not connected. Posteroloph of medium length to long, somewhat shorter than the anteroloph.

M1: Anteroloph medium-long, not connected to protocone or paracone. The lingual part of the anteroloph is very much separated from the protocone. Protoloph strongly oblique, directed towards posterior, where it connects to the protocone, together with the metaloph near the posterolingual border. Precentroloph long. Postcentroloph absent (1), very short (1) or short (2). The centrolophs are not interconnected. Posteroloph transverse, not connected to paracone or protocone (3) (Fig. 6/17) or to the protocone only (1) (Fig. 6/16). No accessory crests neither inside nor outside the trigone.

M2: Subrectangular, broader than long. Anteroloph not connected to the protocone nor to the paracone. The lingual portion of the anteroloph is separated from the protocone, but not as much as in M1. Protoloph oblique, connected to the protocone near the transverse metaloph. Precentroloph very long. Postcentroloph of medium length, not connected to the precentroloph. Posteroloph not connected to the protocone nor to the paracone (1) or to the protocone only (1).

M3: Subtrapezoidal. The anterior part is quite broader than the posterior part. Endoloph continuous. The cusps and crests of the labial wall are connected. The labial and lingual ends of the anteroloph are curved backwards. Protoloph curved posterolingually. Precentroloph of medium length. No accessory crests.

Remarks: The sizes of the specimens from CA2 are, in general, slightly smaller than those from the localities of the Upper Agenian (San Juan) and Lower Ramblian (La Galocha 5) from the Ebro basin, where Peridyromys murinus (Álvarez-Sierra et al., 1990) is found, and much smaller than that of Pseudodryomys ibericus from the same basin. The development of the accessory crests in the $\mathrm{m} 1,2$ from CA2 is very different from P. ibericus, and not exactly the same as in P. murinus. Although Simplomys is not abundant in CA2, the presence of one among three $\mathrm{m} 2$ with accessory crests in the central and posterior valley is clearly different from what happens in P. muri$n u s$, and very similar to what is said in the emended diagnosis (García-Paredes et al., 2009) of Simplomys aljaphi.
The M1,2 of $S$. aljaphi from the type-locality, Montaigu-le-Blin (France), are characterized by having almost parallel protoloph and metaloph, connected to the protocone at the lingual border. The M1,2 of $S$. aff. aljaphi from CA2 have a morphology of these crests (especially of the protoloph) which is quite different from the French population. In the M1 from CA2 that difference is more notable than in the M2. In the M2 from CA2, the protoloph is not as oblique as in the M1. The disposition of the trigone of $S$. aff. aljaphi from CA2 reminds one very much of Peridyromys.

Simplomys is characterized by a reduction of the length of the mesolophid in the $\mathrm{p} 4$ and $\mathrm{m} 3$, which tends to reduce the extension of the posterior valley (García-Paredes et al., 2009). The mesolophid is reduced, and may be connected to the posterolophid at variable height, reducing the posterior valley, as occurs in S. aljaphi from Montaigu-le-Blin, or obliterating it completely, as occurs in many specimens of $S$. julii from the Spanish and French localities of MN3-MN4. In the single p4 from CA2, the mesolophid and the posterolophid are united towards the middle of the tooth, subdividing the posterior valley in two parts. In the process of reduction of the posterior valley that morphology may be interpreted as more primitive, even more so than in the oldest species of the genus, S. aljaphi.

Another primitive morphology observed in the lower molars of Simplomys in CA2 is the development of the centrolophid. According to García-Paredes et al. (2009), the centrolophid in the species of the genus varies from a short prolongation to a well-developed crest that extends in the central valley and that never continues beyond the central axis of the occlusal surface. In this respect, according to these authors, the more derived dental morphology is observed in some of the younger forms of the genus, e.g., S. meulenorum and S. julii. The more primitive morphology corresponds to $S$. aljaphi, the species that conserves the longest centrolophids. In CA2, the length of the centrolophid is even larger than in S. aljaphi, with specimens in which the centrolophid is long, curved and occasionally united to the metalophid, surpassing the middle of the tooth in more than $50 \%$ of the lower molars. According to García-Paredes et al. (2009), that morphology would be the most primitive of the genus.

Genus: Vasseuromys Baudelot and de Bonis, 1966 Type species: Vasseuromys rugosus Baudelot and de Bonis, 1966

Species: cf. Vasseuromys sp.

(Fig. 5/7) 
Locality: Cuesta Agujeros 2 (CA2)

Material and measurements ( $L x W): 1 \mathrm{D} 4$ (CA2-2/22) (6.64 x 9.15).

\section{Description:}

D4: Subtriangular outline. Anteroloph long, low in its lingual part and connected to protocone and paracone. Protoloph oblique, connected lingually in a Y-shape to the slightly oblique metaloph. Postcentroloph longer than the precentroloph. Precentroloph long and interrupted. Postcentroloph connected to the protoloph. No accessory crests between the centrolophs. Metatrope short and lingually united to the postcentroloph. Posteroloph low in its lingual part and connected to protocone and metacone.

Remarks: Only a few D4 of the genus Vasseuromys are known. However, the subtriangular outline of the specimen from CA2 reminds one of the populations from Lower Miocene localities (MN1 and upper part of MN2) of the Ebro basin (Cuenca, 1985; Martínez-Salanova, 1987). The dental pattern of the D4 from CA2 is not as complicated as in $V$. bacchius from Fuenmayor 2 described by Martínez-Salanova (1987), and it is somewhat more complicated than that of $V$. autolensis from the locality Autol 1 (Cuenca, 1985).

Family: Eomyidae Winge, 1887

Eomyidae indet.

(Fig. 4/9)

\section{Locality: Cuesta Agujeros 2 (CA2)}

Material and measurements (L $x$ W): 1 M1 (CA2-2/31) $(6.49 \times 6.63)$

\section{Description:}

M1: Subrectangular-rounded outline. Anteroloph absent. Protoloph curved and low. The mesoloph is long, reaches the labial border and is connected with the protoloph, whereas the posterolingual end is not connected to the metaloph. Longitudinal crest absent. Metaloph connected to the hypocone. Posteroloph curved and connected to the hypocone and to the posterolabial end of the metaloph. Labial and lingual sinus communicate, forming a continuous valley, narrowed in the center by the mesoloph.

Remarks: The specimen in question is difficult to assign to a known species. However, the general morphology is similar to some morphotypes of M1 of the genus Rhodanomys, and to a lesser extent Ritteneria. Among other characters, its long mesoloph reaches the labial border but is not connected to the hypocone. A long mesoloph is common in Rhodanomys transiens from Bergasa and $R$. schlosseri from Autol 1 and Moncalvillo, but the morphology of the anterior part of the mesoloph is quite dif- ferent from these populations, where the mesoloph is always connected to the hypocone (Álvarez-Sierra, 1988). The presence of long mesolophs is uncommon in the species of the genus Ritteneria.

The size of the specimen from CA2 is significantly smaller than any M1 of the species of Rhodanomys and Ritteneria. Its size $(0.649 \times 0.663 \mathrm{~mm})$ is at the limit of the material recovered by the usual screenwashing with $0.5 \mathrm{~mm}$ mesh. It would not be surprising if a large part of the material of this species had been lost in screening.

In the Iberian Peninsula, the last record of the genus Rhodanomys is in MN1 (local zone X) (Álvarez-Sierra, 1988). The accompanying rodent fauna in CA2 (Armantomys daamsi and Eucricetodon aquitanicus, among others) permits to place this locality in the upper part of the Agenian (local zone Y2). The general morphology and the size of the specimen lead us to classify it as Eomyidae indet.

Genus: Ligerimys Stehlin and Schaub, 1951

Type species: Ligerimys florancei Stehlin and Schaub, 1951

Species: Ligerimys aff. magnus Álvarez-Sierra, 1988

(Fig. 4/1-8)

\section{Locality: Cuesta Agujeros 4 (CA4)}

Material: 2 d4 (CA4-1/22, CA4-1/23), 1 p4 (CA41/11), 4 m1,2 (CA4-1, CA4-1/8, CA4-1/9, CA4-1/10), 3 m3 (CA4-1/16, CA4-1/17, CA4-1/21), 3 D4 (CA4-1/14, CA4-1/18, CA4-1/19), 2 M1 (CA4-2, CA4-1/6), 3 M2 (CA4-1/7, CA4-1/13, CA4-1/15) and 1 M3 (CA4-1/20).

Measurements: see Table 5.

\section{Description:}

d4: Anterolophid well developed, united to the lingual and labial end of an oblique metalophid. In one case, at the anterior border, there is a relatively large anterior sinusid. Mesolophid long and complete in one specimen and partially interrupted in the other one.

p4: Anterolophid present, smaller than the metalophid to which it is connected at the lingual and labial end. Mesolophid partially interrupted in the middle of the crest. Hypolophid and posterolophid lingually united, closing the posterosinusid.

m1,2: Anterolophid of small to medium length, connected to the lingual and labial end of the transverse metalophid. Mesolophid complete. Hypolophid and posterolophid lingually united.

m3: Anterolophid short, lingually and labially connected to the metalophid. Mesolophid completely developed and united to the metalophid through the metaconid. 
Mesosinusid lingually open or partially blocked by a low lingual wall. Hypolophid lingually connected to the posterolophid in two of the three specimens. In the third one, these crests are not connected and the hypolophid is connected longitudinally to the posterolophid by a short crest.

D4: The crests are relatively thin and the valleys broad. Anteroloph and protoloph are isolated labially and connected lingually to the protocone. Mesoloph absent. Longitudinal crest present in the three specimens. Metaloph and posteroloph separated labially. Sinus reduced, strongly directed anteriorly, or almost transverse.

M1: The lingual part of the anteroloph curves slightly backward. Anteroloph and protoloph separated labially. Mesoloph absent. Wall of the mesosinus of medium height or low. Metaloph transverse. Metaloph and posteroloph connected to the metacone. Posteroloph curved in its labial part and lingually transverse. Sinus relatively deep and narrow, partially orientated towards anterior.

M2: The anterolabial part is slightly or much higher than the posterior part. Anteroloph and protoloph labially connected at medium height. The lingual part of the

\begin{tabular}{llcccc}
\hline Element & Parameter & $\mathrm{n}$ & min. & mean & max. \\
\hline $\mathrm{d} 4$ & $L$ & 1 & - & 11.43 & - \\
& $W$ & 2 & 7.62 & 7.81 & 8.00 \\
$\mathrm{p} 4$ & $L$ & 1 & - & 12.72 & - \\
& $W$ & 1 & - & 11.46 & - \\
$\mathrm{m} 1.2$ & $L$ & 4 & 11.91 & 12.59 & 13.37 \\
& $W$ & 4 & 11.50 & 11.87 & 12.17 \\
$\mathrm{D} 4$ & $L$ & 3 & 11.22 & 11.55 & 11.79 \\
& $W$ & 3 & 10.53 & 10.65 & 10.73 \\
M1 & $L$ & 2 & 10.22 & 11.47 & 12.71 \\
& $W$ & 2 & 12.56 & 13.47 & 14.38 \\
M2 & $L$ & 3 & 8.96 & 9.99 & 11.30 \\
& $W$ & 3 & 11.60 & 12.52 & 13.99 \\
M3 & $L$ & 1 & - & 8.46 & - \\
& $W$ & 1 & - & 9.80 & - \\
\hline
\end{tabular}

Table 5.- Measurements (in tenths of $\mathrm{mm}$ ) of the teeth of Ligerimys aff. magnus Álvarez-Sierra, 1988 from CA4. Abbreviations: LLength; W-Width; d4-Fourth lower decidual; p4-Fourth lower premolar; m1,2-First or Second lower molar; D4-Fourth upper decidual; M1-First upper molar; M2-Second upper molar; M3Third upper molar.

Tabla 5.- Medidas (en décimas de milímetro) de los dientes de Ligerimys aff. magnus Álvarez-Sierra, 1988 de CA4. Abreviaciones: L-Longitud; W-Anchura; d4 - Cuarto decidual inferior; $\mathrm{p} 4$ Cuarto premolar inferior;; m1,2-Primer o segundo molar inferior; D4 - Cuarto decidual superior; M1 - Primer molar superior; M2 Segundo molar superior; M3 - Tercer molar superior. anteroloph is slightly (1) or strongly (2) directed backwards, leaving the lingual sinus open (1) or almost closing it (2). In the latter two specimens the opening of the lingual sinus is displaced backwards. Protoloph slightly (1) or strongly oblique (2). Mesoloph very short and labial (1) or absent (2). Metaloph transverse (1) or strongly oblique (2). In the latter two specimens, it forms an oblique Y. Posteroloph slightly (1) or strongly (2) curved labially and united to the metacone.

M3: Anteroloph and posteroloph form a circular crest. Protoloph and metaloph parallel, connected labially and lingually with the circular crest, and interconnected by a longitudinal crest somewhat lingually of the tooth axis. No lingual sinus. The labial sinuses are parallel and not connected.

Remarks: The population of Ligerimys found in CA4 is characterized by a much smaller size than Ligerimys magnus from Bañón 2 and 5 and, in general, smaller than Ligerimys aff. magnus from Ramblar 3B and 4A.

The $\mathrm{d} 4$ from CA4 is characterized by the complete or almost complete mesolophid, a morphology that is very similar to that in the localities Ramblar $3 \mathrm{~B}$ and $4 \mathrm{~A}$ and different from the reduced mesolophid of the $\mathrm{d} 4 \mathrm{from}$ Bañón 2 and 5 (Álvarez-Sierra, 1988).

An outstanding feature of the $\mathrm{p} 4$ is the presence of a mesolophid that is complete, but interrupted in the middle, a morphology that is present in $L$. aff. magnus from Ramblar 3B and 4A and absent in L. magnus.

All the m1,2 from CA4 present a complete mesolophid, like in $L$. aff. magnus from Ramblar $3 \mathrm{~B}$ and $4 \mathrm{~A}$, where between $78 \%$ and the $80 \%$ of the specimens show this morphology (Álvarez-Sierra, 1988); this morphology is less frequent in L. magnus: from Bañón 2 (42\%) and Bañón 5 (0\%) (Álvarez-Sierra, 1988).

The M2 from CA4 show two different morphotypes. In the two smaller specimens the strongly backward development of anteroloph, protoloph and metaloph, forms a valley between anteroloph and protoloph that is directed backwards. That morphology is very similar to what is seen in the material of L. magnus from Bañón 2 (Álvarez-Sierra, 1988). The size, especially the width, of the material from CA4 is much smaller than in Bañón 2. The second morphotype of the M2 from CA4 (no. CA4-1/7) does not possess this morphology of the first valley nor the strong backward shift of the lingual sinus. That pattern is very similar to the only morphotype that has been described by Álvarez-Sierra (1988) in L. magnus from the locality of Bañón 5 (Ramblian, zone A) and in $L$. aff. magnus from the localities Ramblar 3B and 4A (Ramblian, zone Z). The size of the specimen CA4-1/7 is comparable to that of $L$. aff. magnus from Ramblar $3 \mathrm{~B}$ and $4 \mathrm{~A}$ (Álvarez-Sierra, 1988). 
In Álvarez-Sierra (1988; fig. 75), the chronological sequence of the localities is: Ramblar 4A, Ramblar 3B (local zone Z), Bañón 5 and Bañón 2 (local zone A). The morphological and biometrical comparison of the material of the genus Ligerimys from Ramblar 4A, Ramblar 3B, Bañón 5, Bañón 2 and CA4 lead us to place CA4 in an age range close to the base of the local zone A of the Ramblian.

The two different morphologies of the M2 from CA4 pose the question of the presence of two species of the genus Ligerimys in CA4, as did Álvarez-Sierra (1988) by distinguishing L. magnus (Bañón 2 and 5) and $L$. aff. magnus (Ramblar 3B and 4A). The diagnosis of $L$. magnus characterized the species as being of large size and having an M2 with a backward directed anteroloph that almost closes the lingual sinus. The measurements of the M2 from Bañón 2 and CA4 with this morphology are very different. Moreover, this typical morphology of the M2 is not unique in CA4, nor in Bañón 2 (Álvarez-Sierra, 1988, pl. 23, figs. 7 and 9). Until more material from CA4 is available we classify these specimens as Ligerimys aff. magnus, though different from Ligerimys aff. magnus from the localities Ramblar 3B and 4A as described by Álvarez-Sierra (1988).

Genus: Pseudotheridomys Schlosser, 1926

Type species: Pseudotheridomys parvulus (Schlosser, 1884)

Species: Pseudotheridomys sp.

(Fig. 4/10)

\section{Locality: Cuesta Agujeros 4 (CA4)}

Material and measurements $(L x W)$ : 1 D4 (CA41/12) ( x 10.48).

\section{Description:}

D4: Tooth with five lophs. The anteroloph low connected to the protoloph at the labial border. Labial end of the protoloph not connected to the labial end of the mesoloph. The second valley is labially open. Mesoloph, metaloph and posteroloph connected at the labial border. The third valley is the largest of the four. The posteroloph is a small crest from the middle of the metaloph curving at its labial end and connecting to the metaloph. The posterosinus is very narrow, being the smallest valley of the tooth.

Remarks: The most outstanding morphological character of this specimen is the presence of five crests, a feature only cited in the genus Pseudotheridomys (Álvarez-Sierra, 1988). The other specimens of eomyids from CA4 do not have five crests.

The posteroloph of CA4-1/12 is much reduced. The lingual and labial ends of that crest are fused to the metaloph. This morphology has not been cited in any population of the genus Pseudotheridomys from the Lower Miocene. The accompanying fauna in CA4 indicates an Upper Ramblian age, for which the only species known in the Iberian Peninsula is $P$. fejfari (Álvarez-Sierra and Daams, 1987). That species has been found in the localities Bañón 11A and Moratilla 1, and in Rubielos de Mora 2, where de Bruijn and Moltzer (1974) described an eomyid as transitional between Pseudotheridomys and Ligerimys, which was later partially classified as P. fejfari by ÁlvarezSierra and Daams (1987) and Álvarez-Sierra (1988). The D4 is only known from Rubielos of Mora 2. De Bruijn and Moltzer (1974) described it as having five lophs (crests), interconnected at the labial border. That morphology is similar to the specimen from CA4-1/12, though the second syncline in CA4 is open at the labial border, or, in other words, the labial ends of protoloph and mesoloph are not connected.

We classify this specimen as Pseudotheridomys sp. The scarce material impedes a more precise determination.

Family: Sciuridae Fischer, 1817

Genus: Heteroxerus Stehlin and Schaub, 1951

Type species: Xerus grivensis Forsyth Major, 1893

Species: Heteroxerus cf. paulhiacensis Black, 1965 (Fig. 4/16-17)

Locality: Cuesta Agujeros 2 (CA2)

Material and measurements (Lx W): 1 D4 (CA2-3/2)

(15.14 x 15.00), 1 P4 (CA2-3/1) (14.88 x 16.49), $1 \mathrm{~m} 1,2$ (CA2-3/3) (14.16 x 12.77).

\section{Description:}

D4: Anteroloph low. Protoloph low, connected to paracone and protocone. Metacone and metaconule of equal size. A low crest connects the metaconule with the protocone. Hypocone high. Posteroloph low, connected to hypocone and metacone.

P4: Anteroloph low. The protoloph is connected to paracone and protocone. Metacone and metaconule of equal size. A low crest connects the metaconule with the protocone. Hypocone high. Posteroloph connected to hypocone and metacone.

$\mathrm{m} 1,2$ : Very much worn. No anterior cingulum. Mesoconid absent. There is a weak entolophid.

Remarks: The size of the material of Heteroxerus paulhiacensis from CA2 is the same as in the localities Coderet (Hugueney, 1969) and Santa Cilia (Álvarez-Sierra et al., 1990); H. rubricati (Cuenca, 1988) is of the same size too. Morphologically, the scarce material from CA2 is characterized by the presence of a connection between 
metaconule and protocone in $\mathrm{D} 4$ and $\mathrm{P} 4$. That connection is not very frequent, neither in H. rubricati nor in $\mathrm{H}$. lavocati (Cuenca, 1988; Cuenca, 1991), and more frequent in H. paulhiacensis (Black, 1965; Álvarez-Sierra et al., 1990). The scarce material of this taxon from CA2 impedes a more precise determination.

Family: Castoridae Hemprich, 1820

Genus: Steneofiber Geoffroy-Saint-Hilaire, 1833

Type species: Steneofiber eseri (Von Meyer, 1846)

Species: Steneofiber sp.

(Fig. 3/5)

Locality: Cuesta Agujeros 4 (CA4)

Material: 1 I (CA4-8).

Description:

I sup: The transverse section of the base of the incisor is subtriangular with the labial part flattened and covered by a fine enamel layer.

Remarks: The size and the morphology of the transverse section of the incisor are very similar to what, according to Hugueney (1999b), characterizes the genera Steneofiber, Chalicomys and Castor. However, Castor is significantly larger.

Mörs and Stefen (2010) and Casanovas-Vilar and Alba (2011) questioned the presence of Chalicomys in MN4 - MN6. Both papers consider this presence as doubtful (Casanovas-Vilar and Alba, 2011), or as result of a mistaken identity with Steneofiber depereti or S. subpyrenaicus.

Therefore, the temporal distribution of castorids in the Early Miocene and the presence of a flattened transverse section in CA4-8 seem to indicate a representative of the genus Steneofiber in CA4. We assign it to Steneofiber sp.

Order: Erinaceomorpha Gregory, 1910

Family: Erinaceidae Fischer, 1814

Genus: Galerix Pomel, 1848

Type species: Galerix exilis (de Blainville, 1839)

Species: Galerix sp.

(Fig. 7/1)

\section{Locality: Cuesta Agujeros 4 (CA4)}

Material and measurements ( $L x W)$ : 1 M3 (CA4-6) (1.34 x 1.86)

\section{Description:}

M3: The occlusal outline of the tooth is triangular. The protocone and the paracone are the highest cusps. The metacone is the lowest main cusp. There is a small and thin cingulum at the base of the anterior margin, connect- ed to the base of the parastyle. The parastyle is low, but it protrudes anterolabially in occlusal view. The central basin is closed.

Remarks: The tooth corresponds to an M3 of a Galericini erinaceid. Yet the species cannot be identified, the only genus of Galericini present in the Early Miocene of Spain is Galerix (Van den Hoek Ostende, 2001). Other than general size, the $\mathrm{p} 4, \mathrm{P} 3$, and M1/M2 are diagnostic elements to distinguish between species of Galerix (Van den Hoek Ostende, 2003). Unfortunately, an isolated M3 is insufficient to determine the species from this locality.

Order: Soricomorpha Gregory, 1910

Family: Soricidae Fischer, 1814

Soricidae indet.

(Fig. 7/2)

\section{Locality: Cabezo Carboneras 1 (CC1)}

Material and measurements ( $L \times T R W): 1$ trigonid of a lower molar (m2?) (CC1-5) (- x 0.70)

\section{Description:}

Lower molar (m2?): Only the trigonid is preserved. The protoconid is the highest cusp of the trigonid. The metaconid is a bit lower than the protoconid. The protolophid is short. The paraconid is the lowest cusp of the trigonid. There is a small cingulid at the base of the paralophid. The fragment does not show any pigmented part.

Remarks: This fragment of lower molar does not display any significant trait to identify the taxon further than the family level. This specimen could correspond either to an $\mathrm{m} 1$ or an $\mathrm{m} 2$, but its aspect (rather anteroposteriorly compressed) fits better within the most frequent morphology of an $\mathrm{m} 2$.

Order: Chiroptera Blumenbach, 1779

Chiroptera indet. (Fig. 7/3-4)

Locality: Cuesta Agujeros 4 (CA4)

Material and measurements ( $L x W)$ : 1 M2 (CA4-5) (1.52 x -), 1 lower molar (CA4-7) (- x 0.98)

\section{Description:}

M1/2: Only the labial half of the tooth is preserved. The metacone is the highest cusp. The paracone is somewhat lower than the metacone. The ectoloph is continuous and the mesostyle is not divided. The parastyle is characteristically curved, oriented anterolingually in occlusal view. The metastyle is rather straight. Although the lingual half is not preserved, it seems that the distal margin had a softly pronounced posterior emargination.

Lower molar: Only the talonid is preserved. The talonid displays a myotodont pattern, where the hypoconulid 


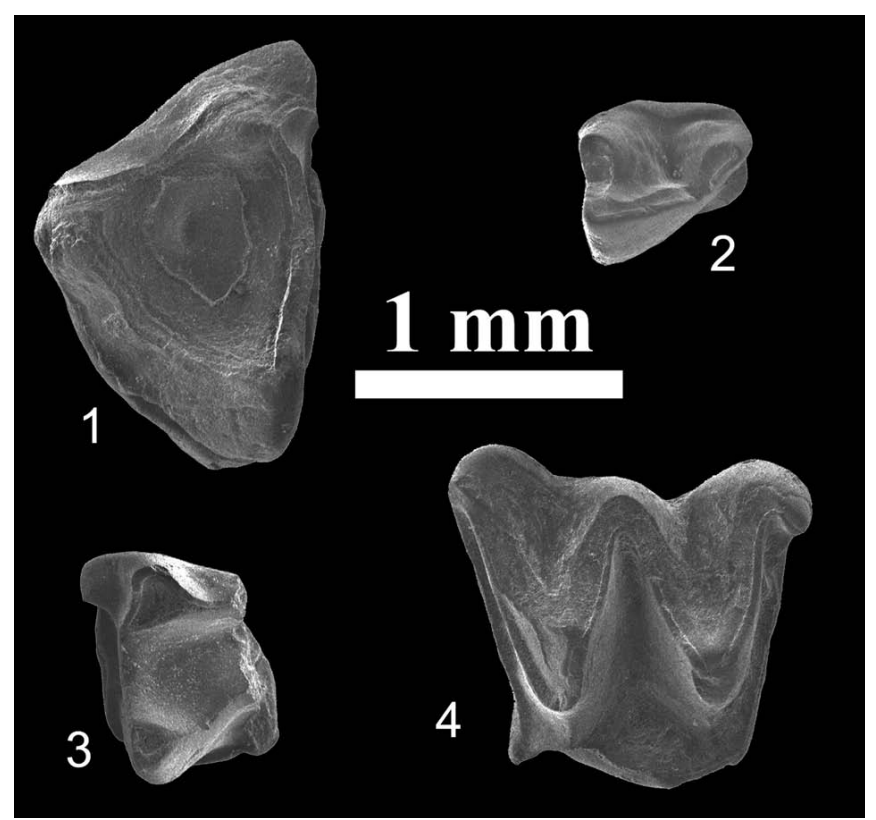

Fig. 7.- Galerix sp. from Cuesta Agujeros 4 (CA4). 1, M3 dext. (CA46); Soricidae indet. from Cabezo Carboneras 1 (CC1). 2, lower molar dext. (CC-5); Chiroptera indet. from Cuesta Agujeros 4 (CA4). 3, lower molar dext. (CA4-7); 4, upper molar dext. (CA4-5). Scale: $1 \mathrm{~mm}$.

Fig. 7.- Galerix sp. de Cuesta Agujeros 4 (CA4). 1, M3 dext. (CA4-6); Soricidae indet. de Cabezo Carboneras 1 (CC1). 2, molar inferior dext. (CC-5); Chiroptera indet. de Cuesta Agujeros 4 (CA4). 3, molar inferior dext. (CA4-7); 4, molar superior dext. (CA4-5). Escala: $1 \mathrm{~mm}$.

is completely separated from the entoconid in a basal posterior position. The hypoconid is the highest cusp of the part talonid. The entoconid is not as high as the hypoconid. There is a thin crest anteriorly connected to the entoconid. There is a continuous well-defined cingulum covering the posterior and the labial bases of the talonid. The oblique cristid descends to half the height from the hypoconid.

Remarks: The two dental elements are broken. The diagnostic traits in isolated upper molars of fossil bats are usually found in the lingual half (Sevilla, 1988), which unfortunately is the missing part in the only $\mathrm{M}$ available. The relative development of the ectoloph crests and the curved parastyle resembles the morphology of Rhinolophus.

The myotodont pattern of the lower molar fragment precludes its attribution to the genus Rhinolophus. However, this element could also correspond to a different species. A generic identification based on such scarce elements would be highly speculative.

\section{Biostratigraphy}

Figure 8 gives the distribution of the taxons in the localities studied in this paper. The localities CH1 and CA1 contain, among other taxons, Eucricetodon cf. gerandi- anus and Armantomys cf. bijmai, an association that is typical for local zone Y1 of the Agenian (Álvarez-Sierra et al., 1987; Daams, 1990; Hugueney, 1999a). CA2 and CC1 contain Eucricetodon aquitanicus and Armantomys daamsi, characteristic elements of zone Y2 of the Agenian (Álvarez-Sierra et al., 1987; Daams, 1990).

In the upper part of the Agenian the record of eomyids is rather scarce (Álvarez-Sierra et al., 1990; Mein, 1999). In the locality San Juan, assigned to local zone Y2 by Álvarez-Sierra et al. (1990), those authors cited the presence of 10 specimens of eomyids in a collection of ca 320 rodent remains ( $3 \%$ of the total). The very scarce representation of eomyids in the upper part of zone $\mathrm{Y}$, and the fact that our collections contain less then 30 specimens per locality, might explain the absence of eomyids in most of them. In the described faunas, remains of eomyids are only present in the locality CA2, where a doubtful specimen of Rhodanomys or Ritteneria has been found (Fig. 8).

The localities CA3 and CA3B contain a scarce fauna, composed by glirids only. The only biostratigraphically relevant taxon is Armantomys cf. parsani from CA3. According to Daams (1990), this taxon is present throughout the upper part of the Agenian (local zone Y2) and the Ramblian (local zones $\mathrm{Z}$ and A). The locality is stratigraphically intermediate between CM1 and CJ1, both belonging to local zone Z (Murelaga et al., 2004a), and therefore placed in the same zone. On the other hand, CA3B is only 13 meters below CA4, attributed to local zone $\mathrm{A}$. This means that the limit between zones $\mathrm{Z}$ and $\mathrm{A}$ is situated in the higher part of the section of Cuesta Agujeros, and has an age of ca. 19.45 Ma (Figs. 2 and 8).

Stratigraphically, CA4 is the highest of the studied localities. It contains Pseudotheridomys sp., Ligerimys aff. magnus and Armantomys cf. jasperi. Pseudotheridomys is represented by a single specimen, not classified at species level. The genus has a stratigraphic distribution from the upper part of the Oligocene (local zone W) to the Lower Aragonian (local zone B) (Fig. 8). In the Iberian Peninsula, Álvarez-Sierra (1988) cited the presence of Pseudotheridomys in the age range between local zones $\mathrm{W}$ and $\mathrm{Y} 2$ and in the localities Bañón 11A and Moratilla 1, of the local zone A. Other Iberian localities of zone A that contain a member of the genus Pseudotheridomys are Rubielos de Mora 2 (transitional association between PseudothyeridomysLigerimys in de Bruijn and Moltzer, 1974; Álvarez-Sierra and Daams, 1987) and Alto de Ballester (Ruiz-Sánchez, 1992; Montoya et al., 1996), both situated in the basin of Rubielos de Mora. There is no record of Pseudotheridomys in localities of the Lower Ramblian (local zone Z) in the Iberian Peninsula. In Central Europe, Engesser (1999) and Pippèrr et al. (2007), cite the presence of Pseudoth- 


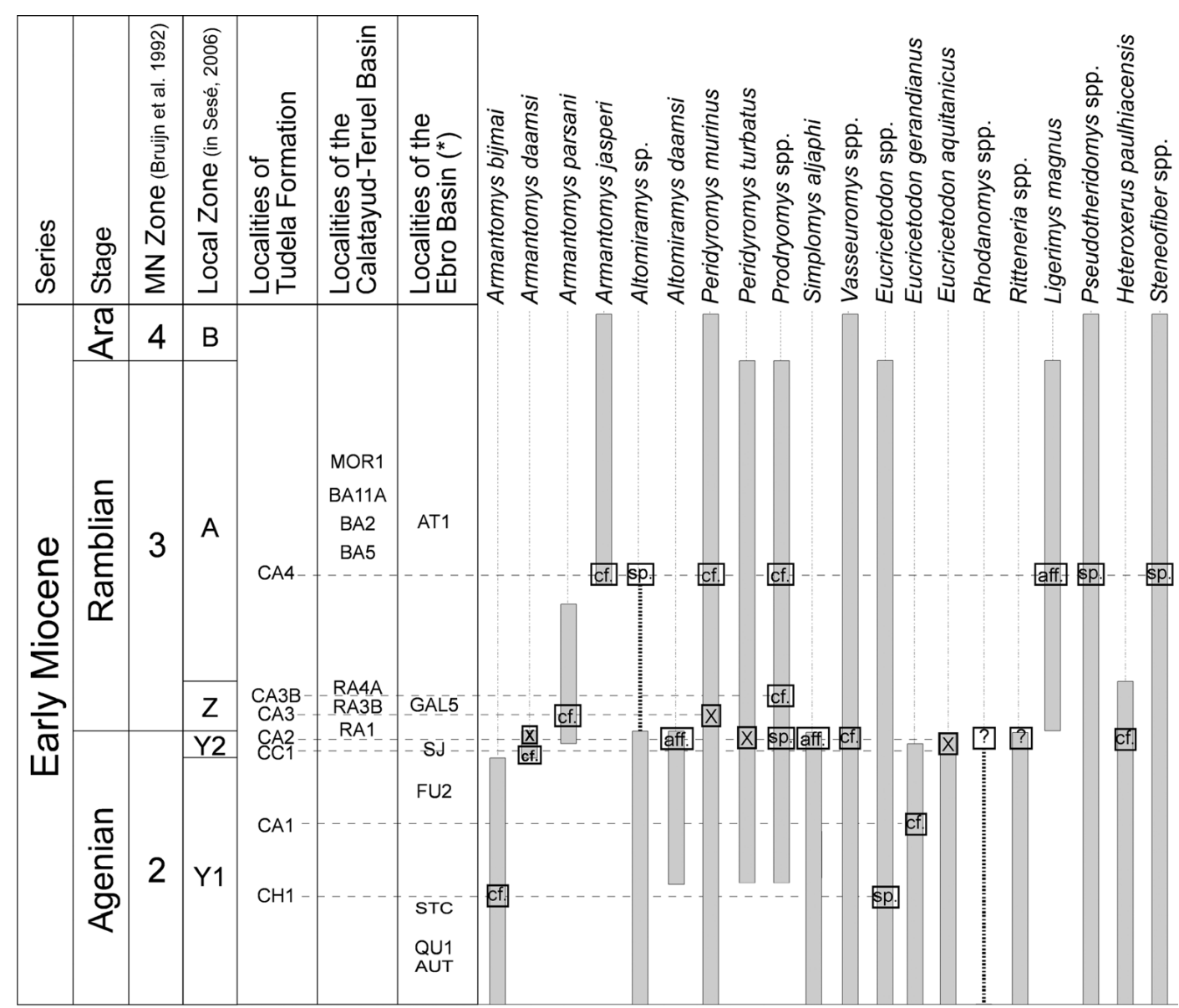

Fig. 8.- Distribution of the rodents species studied in this work and in Daams and Freudenthal (1988), Lacomba and Martínez-Salanova (1988), Álvarez-Sierra et al. (1990), and Daams (1990). The succession of localities is in stratigraphic order, but not on scale. Abbreviations: CH1 — Cabezo Hermoso 1; CA1—Cuesta Agujeros 1; CC1—Cabezo Carboneras 1; CA2 - Cuesta Agujeros 2; CA3 - Cuesta Agujeros 3; CA3B-Cuesta Agujeros 3B; CA4 - Cuesta Agujeros 4; RA1—Ramblar 1; RA3B-Ramblar 3B; RA4A-Ramblar 4A; BA5-Bañón 5; BA2-Bañón 2; BA11A-Bañón 11A; MOR1-Moratilla 1; AUT-Autol 1; STC-Santa Cilia; QU1-Quel 1; FU2-Fuenmayor 2; SJ-San Juan; GAL5—La Galocha 5; AT1-Ateca 1. Ara-Aragonian. (*) — Localities of the Tudela Formation not included.

Fig. 8.- Distribución de las especies de roedores estudiadas en este trabajo y en Daams and Freudenthal (1988), Lacomba and MartínezSalanova (1988), Álvarez-Sierra et al. (1990), y Daams (1990). La sucesión de localidades se presenta en orden estratigráfico pero no a escala. Abbreviations: CH1 - Cabezo Hermoso 1; CA1 - Cuesta Agujeros 1; CC1—Cabezo Carboneras 1; CA2 - Cuesta Agujeros 2; CA3 - Cuesta Agujeros 3; CA3B - Cuesta Agujeros 3B; CA4 - Cuesta Agujeros 4; RA1—Ramblar 1; RA3B-Ramblar 3B; RA4ARamblar 4A; BA5-Bañón 5; BA2-Bañón 2; BA11A—Bañón 11A; MOR1-Moratilla 1; AUT-Autol 1; STC—Santa Cilia; QU1Quel 1; FU2_Fuenmayor 2; SJ—San Juan; GAL5—La Galocha 5; AT1—Ateca 1. Ara-Aragonian. (*)— No incluidas las localidades de la Formación Tudela.

eridomys n. sp. in the lower part of the MN4.

As far as Ligerimys aff. magnus is concerned, ÁlvarezSierra (1988) cited the presence of a similar form, but slightly smaller than Ligerimys magnus, in the localities Ramblar 3B and Ramblar 4A of zone $\mathrm{Z}$ of the Ramblian and in the localities Bañón 2 and Bañón 5 of zone A, also Ramblian. The morphology of Ligerimys aff. magnus from CA4 is very similar to Ligerimys magnus of zone A, though its size is clearly smaller.

The stratigraphic distribution of Armantomys cf. jasperi covers the Upper Ramblian (local zone A) through the Middle Aragonian (local zone D2 in Daams, 1990; Dc in van der Meulen et al., 2012). The co-occurrence of Pseudotheridomys sp., Ligerimys aff. magnus and Armantomys cf. jasperi leads us to place the locality CA4 in local zone A of the Ramblian.

The data of the rodent faunas from the localities of the Tudela Formation studied in the present work corroborate the biostratigraphical results of Ruiz-Sánchez et al. (2012), based exclusively on the hypsodont Gliridae from the same localities.

\section{Conclusions}

Seven new localities have been found in the Tudela Formation (CH1, CA1, CA2, CC1, CA3, CA3B and 
CA4), covering the time interval between the MiddleLate Agenian (MN2) and the Late Ramblian (upper part of MN3).

In the faunas from the localities of the Agenian four forms of Cricetidae are represented, eight Gliridae, one Sciuridae and one Eomyidae. The faunas from the localities of the Early Ramblian are restricted to three forms of Gliridae. Finally, in the single fauna of the Late Ramblian (CA4) are represented four forms of Gliridae, two Eomyidae and one Castoridae.

The relative abundance and high species diversity of the Gliridae in both the Agenian and the Ramblian are important features, as well as the absence of Cricetidae in the localities of the Ramblian.

The discovery of an eomyid (Rhodanomys or Ritteneria) in the locality CA2 constitutes the first record of this taxon in the Iberian Peninsula in deposits of Late Agenian age.

The record of Altomiramys sp. in CA4 is the first one of this taxon in the Upper Ramblian.

The morphology of Simplomys aff. aljaphi from CA2 represents an evolutionary stage a slighty different to the oldest described forms of the genus and probably demonstrates close phylogenetic relationship with the genus Peridyromys.

Unfortunately, the record of insectivores and bats in the Tudela Formation is rather anecdotic, and they cannot refine the information provided by rodents.

The distribution of the species studied permits to assign the localities $\mathrm{CH} 1$ and $\mathrm{CA} 1$ to local zone Y1 (lower part of zone MN2), CA2 and CC1 to local zone Y2 (upper part of zone MN2), CA3 and CA3B presumably to local zone $\mathrm{Z}$ (lower part of zone MN3), and finally, CA4 to local zone A (upper part of zone MN3).

\section{Acknowledgements}

Alejandro Urmeneta and Rubén Arcos of the 'Comunidad of the Bardenas Reales of Navarra' and Eliseo Martínez and Salvador García of the 'Aula Paleontológica of Cenicero' assisted in the sampling campaigns, for which we are very grateful. We appreciate the efficient help of the technicians of the SCSIE of the UV, P. Gómez and E. Navarro. The observations of Dr. Israel García-Paredes on the material of the genus Simplomys from CA2 have contributed to improve the original manuscript considerably. We thank to Dr. Lars van den Hoek Ostende and an anonymous reviewer for their comments and criticism. This investigation was financed through the projects BTE2003-7252, CGL2004-0780, CGL2007/66431/C0202, GVPRE/2008/320 and CGL2011-28681.

\section{References}

Aguilar, J.P. (1974): Les rongeurs du Miocène inférieur en BasLanguedoc et les corrélations entre échelles stratigraphiques marine et continentale. Geobios 7 (4), 345-398. doi:10.1016/S00166995(74)80015-X.

Alonso-Zarza, A.M., Armenteros, A., Braga, J.C., Muñoz, A., Pujalte, V., Ramos, E. Aguirre, J., Alonso-Gavilán, G., Arenas, C., Baceta, J.I., Carballeira, J., Calvo, J.P., Corrochano, A., Fornós, J.J., González, A., Luzón, A., Martín, J.M., Pardo, G., Payros, A., Pérez, A., Pomar, L., Rodríguez, J.M., Villena, J. (2002): Tertiary. In: W. Gibbons and T. Moreno (eds.), The Geology of Spain. Geological Society, Londres, 293-334.

Álvarez-Sierra, M.A. (1988): Estudio sistemático y bioestratigráfico de los Eomyidae (Rodentia, Mammalia) del Oligoceno superior y Mioceno inferior español. Scripta Geologica 86, 1-207.

Álvarez-Sierra, M.A., Daams, R. (1987): Pseudotheridomys fejfari, a new species of Eomyidae (Rodentia) from the Ramblian (Lower Miocene) of northern Teruel (Spain). Scripta Geologica 83, 19-26.

Álvarez-Sierra, M.A., Daams, R., Lacomba, J.I., López-Martínez, N., Sacristán-Martín, M.A. (1987): Succession of micromammal faunas in the Oligocene of Spain. Münchner Geowissenschaftliche Abhandlungen 10, 43-48.

Álvarez-Sierra, M.A., Daams, R., Lacomba, J.I., López-Martínez, N., van der Meulen, A.J., Sesé, C., de Visser, J. (1990): Palaeontology and biostratigraphy (micromammals) of the continental OligoceneMiocene deposits of the North-Central Ebro Basin (Huesca, Spain). Scripta Geologica 94, 1-77.

Arenas, C., Pardo, G. (1999): Latest Oligocene-late Miocene lacustrine systems of the north-central part of the Ebro Basin (Spain): sedimentary facies model and paleogeographic síntesis. Palaeogeography, Palaeoclimatology, Palaeoecology 151, 127-148.

Baudelot, S., de Bonis, L. (1966): Nouveaux Gliridés (Rodentia) de l'Aquitanien du basin d'Aquitaine. Comptes Rendus Sommaires Societé Geologique de la France 9, 342-343.

Baudelot, S., de Bonis, L. (1968): Contribution à l'étude des rongeurs de l'Aquitanien du Bassin d'Aquitaine. Bulletin de la Société d'Histoire Naturelle de Toulouse 104, 160-164.

Black, C.C. (1965): New species of Heteroxerus (Rodentia, Sciuridae) in the French Tertiary. Verhandlungen der Naturforschenden Gesellschaft in Basel 76, 185-196.

Bruijn, H. de (1966): Some new Miocene Gliridae from the Calatayud area (Prov. Zaragoza, Spain). Proceedings Koninklijke Nederlandse Akademie van Wetenschappen B 69, 58-78.

Bruijn, H. de, Moltzer, J. (1974): The rodents from Rubielos de Mora; The first evidence of the existente of different biotopes in the Early Miocene of eastern Spain. Proceedings Koninklijke Nederlandse Akademie van Wetenschappen B 77, 129-145.

Casanovas-Vilar, I., Alba, D.M. (2011): The never-ending problem of Miocene beaver taxonomy. Acta Palaeontologica Polonica 56 (1), 217-220. doi:10.4202/app.2010.0051.

Costa, E., Garcés, M., López-Blanco, M., Beamud, E., Gómez-Paccard, M., Larrasoaña, J.C. (2010): Closing and continentalization of the South Pyrenean foreland basin (NE Spain): magnetochronological constraints. Basin Research 22, 904-917. doi:10.1111/j.13652117.2009.00452.x.

Cuenca, G. (1985): Los roedores (Mammalia) del Mioceno inferior de Autol (La Rioja). Ediciones del Instituto de Estudios RiojanosCiencias de la Tierra 2, 1-96.

Cuenca, G. (1988): Revisión de los Sciuridae del Aragoniense y del Rambliense en la fosa de Calatayud - Montalbán. In: M. Freudenthal (ed.), Biostratigraphy and paleoecology of the Neogene micro- 
mammalian faunas from the Calatayud-Teruel Basin (Spain). Scripta Geologica, Special Issue 2, Leiden: 1-116.

Cuenca, G. (1991): Quelques problèmes dans la classification des Sciuridae fossiles, un exemple dans le genre Heteroxerus. In: M. Le Berre and L. Le Guelte (eds.), Colloque Le Rongeur et L'espace, Paris: 195-202.

Daams, R. (1974): Pseudodryomys (Gliridae, Rodentia, Mammalia) from Early and Middle Miocene deposits in Spain. Proceedings Koninklijke Nederlandse Akademie van Wetenschappen 77, 201-240.

Daams, R. (1981): The dental pattern of the Dormice Dryomys, Myomimus, Microdyromys and Peridyromys. Utrecht Micropaleontological Bulletin 3, 1-115.

Daams, R. (1989): Miscellaneous Gliridae from the Miocene of the Calatayud-Teruel Basin, Aragón, Spain. Scripta Geologica 89, 13 26.

Daams, R. (1990). Hypsodont Myomiminae (Gliridae, Rodentia) from the Miocene and the Oligocene-Miocene boundary interval of Spain. Scripta Geologica 95, 1-63.

Daams, R. (1999): Family Gliridae. In: G. E. Rössner and K. Heissig (eds.), The Miocene Land Mammals of Europe. Verlag Dr. Friedrich Pfeil, München: 301-318.

Daams, R., Freudenthal, M. (1988). Synopsis of the Dutch-Spanish collaboration program in the Aragonian type area, 1975-1986. In: M. Freudenthal (ed.), Biostratigraphy and paleoecology of the Neogene micromammalian faunas from the Calatayud-Teruel Basin (Spain). Scripta Geologica, Special Issue 1, Leiden: 3-18.

Daams, R., van der Meulen, A.J., Álvarez Sierra, M.A., Peláez Campomanes, P., Krijgsman, W. (1999): Aragonian stratigraphy reconsidered, and a re-evaluation of the middle Miocene mammal biochronology in Europe. Earth and Planetary Science Letters 165, 287-294. doi:10.1016/S0012-821X(98)00273-8.

Díaz-Molina, M., López-Martínez, N. (1979): El Terciario continental de la Depresión Intermedia (Cuenca). Bioestratigrafía y Paleogeografía. Estudios Geológicos 35, 149-167.

Engesser, B. (1999): Family Eomyidae. In: G. E. Rössner and K. Heissig (eds.), The Miocene Land Mammals of Europe. Verlag Dr. Friedrich Pfeil, München: 319-335.

Fahlbusch, V. (1970): Populationsverschiebungen bei tertüiren Nagetieren, eine Studie an oligozanen und miozanen Eomyidae Europas. Bayerische Akademie der Wissenschaften MathermatischNaturwissenschaftliche Klasse. Neue Folge 145, 1-136.

Freudenthal, M. (2004): Gliridae (Rodentia, Mammalia) from the Eocene and Oligocene of the Sierra Palomera (Teruel, Spain). Treballs del Museu de Geologia de Barcelona 12, 97-173.

García-Paredes, I., Peláez-Campomanes, P., Álvarez-Sierra, M.A. (2009): Gliridae (Rodentia, Mammalia) with a simple dental pattern: a new genus a new species from the European Early and Middle Miocene. Zoological Journal of the Linnean Society 157, 622-652. doi: 10.1111/j.1096-3642.2009.00527.x.

Geoffroy Saint-Hilaire, E.F. (1833): Considérations sur des ossements fossiles la plupart inconnus, trouvés et observés dans les bassins de l'Auvergne. Revue encyclopédique (Paris) 59, 76-95.

Hoek Ostende, L.W. van den (2001): A revised generic classification of the Galericini (Insectivora, Mammalia) with some remarks on their palaeobiogeography and phylogeny. Geobios 34(6), 681-695. doi:10.1016/S0016-6995(01)80029-2.

Hoek Ostende, L.W. van den (2003): Insectivores (Erinaceomorpha, Soricomorpha, Mammalia) from the Ramblian of the Daroca-Calamocha area. Coloquios de Paleontología, Volumen Extraordinario 1,281-310.

Hugueney, M. (1969): Les rongeurs (Mammalia) de l'Oligocène supérieur de Coderet-Bransat (Allier). Documents du Laboratoire de Géologie de la Faculté des Sciences de Lyon 34, 1-227.
Hugueney, M. (1999a): Genera Eucricetodon and Pseudocricetodon. In: G. E. Rössner and K. Heissig (eds.), The Miocene Land Mammals of Europe. Verlag Dr. Friedrich Pfeil, München: 347-358.

Hugueney, M. (1999b): Familiy Castoridae. In: G. E. Rössner and K. Heissig (eds.), The Miocene Land Mammals of Europe. Verlag Dr. Friedrich Pfeil, München: 281-300.

Hugueney, M., Collier, A., Huin, J., Olivier, P. (1978): Un gliride nouveau du Miocene de Montaigu-le-Blin (Allier): Pseudodryomys aljaphi nov. sp. (Mammalia, Rodentia). Revue Scientifique du Bourbonnais 1978, 27-45.

Lacomba, J.I., Martínez-Salanova, J. (1988): Quercomys bijmai gen. nov. sp. nov. (Gliridae, Rodentia, Mammalia) del tránsito Oligoceno-Mioceno español. Estudios Geológicos 44, 107-118. doi: 10.3989/egeol.88441-2.

Larrasoaña, J.C., Murelaga, X., Garcés, M. (2006): Magnetobiochronology of Lower Miocene (Ramblian) continental sediments from the Tudela Formation (western Ebro basin, Spain). Earth and Planetary Science Letters 243, 409-423. doi: 10.1016/j.eps1.2006.01.034.

Lourens, L.J., Hilgen, F.J., Shackleton, N.J., Laskar, J., Wilson, D.S. (2004): The Neogene period. In: F. N. Gradstein, J. G. Ogg and A. G. Smith (eds.), A Geologic Time Scale 2004. Cambridge University Press, Cambridge: 409-440.

Martínez-Salanova, J. (1987): Estudio paleontológico de los micromamíferos del Mioceno inferior de Fuenmayor (La Rioja). Ediciones del Instituto de Estudios Riojanos-Ciencias de la Tierra 10, 1-99.

Mayr, H. (1979): Gebissmorphologische Untersuchungen an miozänen Gliriden (Mammalia, Rodentia) Süddeutschlands. Ph.D. Thesis. University of München: $380 \mathrm{pp}$.

Mein, P. (1999): European Miocene Mammal Biochronology. In: G. E. Rössner and K. Heissig (eds.), The Miocene Land Mammals of Europe. Verlag Dr. Friedrich Pfeil, München: 25-38.

Mein, P., Freudenthal, M. (1971): Les Cricetidae (Mammalia, Rodentia) du Néogène Moyen de Vieux-Collonges. Partie 1: Le genre Cricetodon Lartet, 1851. Scripta Geologica 5, 1-51.

Meulen, A.J. van der, García-Paredes, I., Álvarez-Sierra, M.A., Van den Hoek Ostende, L.W., Hordijk, K., Oliver, A., Peláez-Campomanes, P. (2012): Updated Aragonian biostratigraphy: Small Mammal distribution and its implications for the Miocene European Chronology. Geologica Acta 10(1), 1-24.

Montoya, P., Peñalver, E., Ruiz-Sánchez, F.J., Santisteban, C., Alcalá, L., Belinchón, M., Lacomba, J.I. (1996): Los yacimientos paleontológicos de la cuenca terciaria continental de Rubielos de Mora (Aragón). Revista Española de Paleontología no extr., 215-224.

Mörs, T., Stefen, C. (2010): The castorid Steneofiber from NW Germany and its implications for the taxonomy of Miocene beavers. Acta Palaeontologica Polonica 55, 189-198. doi: http://dx.doi. org/10.4202/app.2009.0013.

Murelaga, X. (2000): Estudio de las faunas de vertebrados del Mioceno inferior de las Bardenas Reales de Navarra y áreas colindantes (Cuenca del Ebro, Navarra). Ph.D. Thesis, Universidad del País Vasco / Euskal Herriko: 363 pp.

Murelaga, X., Pereda-Suberbiola X., Lapparent de Broin, F., Rage, J.C., Duffaud, S., Astibia, H., Badiola, A. (2002): Reptiles and amphibians from the Lower Miocene of the Bardenas Reales of Navarra (Ebro basin, Iberian Peninsula). Geobios 35, 347-365. doi:10.1016/S0016-6995(02)00031-1.

Murelaga, X., Astibia, H., Sesé, C., Soria, D., Pereda-Suberbiola X. (2004a): Mamíferos del Mioceno inferior de las Bardenas Reales de Navarra (Cuenca del Ebro, Península Ibérica). Munibe 55, 7-102.

Murelaga, X., Larrasoaña, J.C., Garcés, M. (2004b): Nueva localidad fosilífera en el Mioceno inferior de las Bardenas Reales de Navarra (Cuenca del Ebro, Península Ibérica). Geogaceta 36, 179-182.

Pomel, A. (1853): Catalogue méthodique et descriptif des Vertébrés 
fossiles découverts dans le Bassin hydrographique supérieur de la Loire et surtout de son principal affluent, l'Allier. J.B. Baillère, Paris, $193 \mathrm{pp}$

Pippèrr, M., Reichenbacher, B., Witt, W., Rocholl, A. (2007): The Middle and Upper Ottnangian of the Simssee area (SE Germany): Micropalaeontology, biostratigraphy and chronostratigraphy. Neues Jahrbuch für Geologie und Paläontologie Abhandlungen 245 (3), 353-378. doi: 10.1127/0077-7749/2007/0245-0353.

Ruiz-Sánchez, F.J. (1992): Alto de Ballester: un nuevo yacimiento de mamíferos del Mioceno inferior de la cuenca de Rubielos de Mora. Trabajo de investigación curso de doctorado, Universitat de València: 94 pp. (unpublished).

Ruiz-Sánchez, F.J., Murelaga, X., Freudenthal, M., Larrasoaña, J.C., Garcés, M. (in press): Hypsodont Myomiminae (Gliridae, Rodentia) from five new localities in the Lower Miocene Tudela Formation (Bardenas Reales, Ebro Basin, Spain) and their bearing on the age of the Agenian-Ramblian boundary. Geodiversitas 34(3), 645663. http://dx.doi.org/10.5252/g2012n3a10.
Schaub, S. (1925): Die hamsterartigen Nagetiere des Tertiärs und ihre lebenden Verwandten. Abhandlungen der Schweizerischen Paläontologischen Gesellschaft 45, 1-114.

Schlosser, M. (1926): Die Säugetierfauna von Peublanc (Dep. Allier). Society Science Nature Croatica 38/39, 372-394.

Sevilla, P. (1988): Estudio paleontológico de los Quirópteros del Cuaternario español. Paleontologia i Evolució 22, 113-233.

Stehlin, H.G., Schaub, S. (1951): Die Trigonodontie der simplicidentaten Nager. Schweizerische Paläontologische Abhandlungen 67, $1-385$.

Thaler, L. (1966): Les rongeurs fósiles du Bas-Languedoc dans leurs raports avec l'histoire des faunes et la stratigraphie du Tertiaire d'Europe. Mémoires du Muséum Nacional d'Histoire Naturelle 17, $1-295$.

Urgeles, R., Camerlenghi, A., García-Castellanos, D., De Mol, B., Garcés, M., Vergés, J., Haslam, I., Hardmann, M. (2011): New constraints on the Messinian sealevel drawdown from 3D seismic data of the Ebro Margin, western Mediterranean. Basin Research 23, 123-145. doi: 10.1111/j.1365-2117.2010.00477.x. 